Int. J. Dev. Biol. 52: 857-871 (2008)

doi: $10.1387 / \mathrm{ijdb} .072416 \mathrm{mf}$

\title{
The Apical Ectodermal Ridge: morphological aspects and signaling pathways
}

\author{
MARIAN FERNANDEZ-TERAN ${ }^{1}$ and MARIA A. ROS ${ }^{*, 2}$ \\ ${ }^{1}$ Departamento de Anatomía y Biología Celular. Universidad de Cantabria and \\ ${ }^{2}$ Instituto de Biomedicina y Biotecnología de Cantabria, IBBTEC (CSIC-UC-IDICAN), Santander, Spain.
}

\begin{abstract}
The Apical Ectodermal Ridge (AER) is one of the main signaling centers during limb development. It controls outgrowth and patterning in the proximo-distal axis. In the last few years a considerable amount of new data regarding the cellular and molecular mechanisms underlying AER function and structure has been obtained. In this review, we describe and discuss current knowledge of the regulatory networks which control the induction, maturation and regression of the AER, as well as the link between dorso-ventral patterning and the formation and position of the AER. Our aim is to integrate both recent and old knowledge to produce a wider picture of the AER which enhances our understanding of this relevant structure.
\end{abstract}

KEY WORDS: apical ectodermal ridge, AER, limb development, FGF, dorso-ventral patterning, double ridge

\section{Introduction}

During development, the formation of a new organism results from the coordinated combination of multiple processes including growth, patterning and cell death. Among the major established models to study these fundamental processes is the developing vertebrate limb. One of the greatest advantages of the developing limb is that it is not a vital organ and so, therefore, genetic or experimental manipulations that even completely disrupt its formation are still compatible with embryo survival.

An important part of the body of knowledge concerning limb development was generated by pioneer experimental manipulations of the chick wing bud performed in the second half of the past century. The chick was used as a preferential study model because of the great advantage of easy accessibility and experimental manipulation. These early studies enabled definition of the main cellular interactions and patterning events underlying limb development and laid the foundations for subsequent molecular studies (see, for example, Hinchliffe and Johnson, 1980). More recently, in the molecular era, the mouse model with its possibilities for genetic manipulation and other animal models such us the zebrafish have permitted us to complete and expand previous knowledge particularly with the addition of the information about the molecules and genes involved.

The basic configuration of the amniote limb includes three main segments that from body wall to distal tip are called the stylopod, the zeugopod and the autopod. The stylopod and the zeugopod contain one and two skeletal elements respectively and are highly conserved across species. In contrast, the distal segment or autopod, which contains the multiple skeletal elements of the hand/foot including the digits, is subject to considerable evolutionary variation. It is presently accepted that all extant tetrapods descend from a common ancestor that had limbs with five digits (pentadactyl limbs). While many species have reduced the number of digits or even lost the limb, there does appear to exist a limit to the maximum number of digits (Cohn and Tickle, 1999; Cohn, 2001). In the vertebrate autopod digits are designated from 1 to 5 starting from the anterior border. The identity of each digit is ascribed based on its size, length, number of phalanges and relative position in the digital plate. Characteristically, the first digit of the human and mouse autopod has two phalanges while the rest of the digits have three. However, when one or more digits are missing, because of evolutionary change or malformations, the identity of the remaining digits is not usually easy to determine. A typical example is that of the bird wing, whose three digits, based on embryologic evidence, can be classified as digits 2, 3 and 4 but which, based on the fossil record and on gene expression, can also be classified as digits 1,2 and

Abbreviations used in this paper: AER, apical ectodermal ridge; FGF, fibroblast growth factor.

*Address correspondence to: Marian Ros. Departamento de Anatomía y Biología Celular, Universidad de Cantabria, Herrera Oria s/n, 39011 Santander. Fax: 34-942-201-903. e-mail: rosm@unican.es

Published online: 11th August 2008 
3 (Vargas and Fallon, 2005).

The first morphological indication of limb development is the appearance of symmetric slight swellings in the lateral body wall at about 51-56 hours of incubation in the chick embryo (Fig. 1A-B) (stage 16 of Hamburger and Hamilton, 1951) and at about embryonic developmental day (E) 9,5 in the mouse embryo (Wanek etal., 1989; Fernández-Terán et al., 2006). These swellings extend from the level of the $15^{\text {th }}$ to $20^{\text {th }}$ somite in the chick and from the $7^{\text {th }}$ to $12^{\text {th }}$ in the mouse and are called the forelimb bud or limb anlage (Ger. Primordium). Similar swellings opposite the $26^{\text {th }}$ to $32^{\text {nd }}$ somites in the chick and from the $23^{\text {rd }}$ to $28^{\text {th }}$ in the mouse indicate the emergence of the hindlimb buds. Curiously, the time between the emergence of fore and hindlimbs is much narrower in the chick than in the mouse. These early limb buds result from the accumulation of somatopleural cells under the surface ectoderm and are, therefore, composed of a mesenchyme of mesodermal origin covered by the ectoderm (Fig.1C). From the earliest stages, the mesenchyme of the limb buds becomes heterogeneous due to the colonization by migrating endothelial and muscular precursor cells
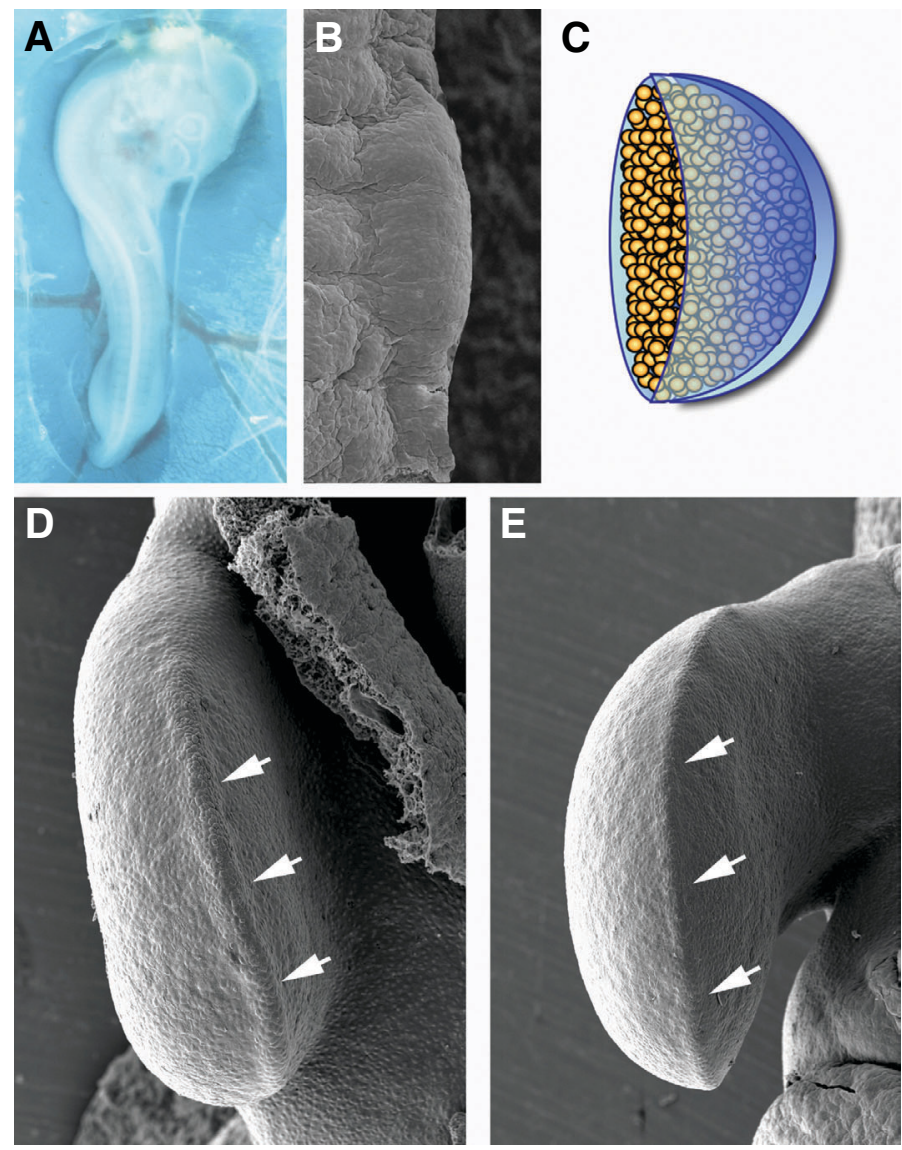

Fig. 1. Overview of limb development. (A) View of a stage $17 H$ H chick embryo in ovo. Note the presence of the four limb buds. (B) Microphotograph of scanning microscopy showing the dorsal view of the early anlage of a stage $16 \mathrm{HH}$ wing bud. (C) Diagram of the early limb bud in which the two main components are clearly indicated. Ectoderm is depicted in blue and mesodermal cells in yellow. (D) Distal view of a stage $23 \mathrm{HH}$ wing bud. (E) Distal view of a stage 26 wing bud. The prominence of the AER is seen in both wings. Note that the AER is more marked at stage $23 \mathrm{HH}$ than a stage $26 \mathrm{HH}$. In all the panels anterior is to the top. that come from the somites (Tozer and Duprez, 2005; Tozer et al., 2007).

After the initial budding, further limb development proceeds relying on multiple intercellular interactions, the main ones of which are directed by three signaling centers that become established in the bud as it emerges (reviewed in Mariani and Martin, 2003; Niswander, 2003; Tickle, 2003; Mackem, 2005). Each signaling center controls patterning in one of the main axes of the limb and they are all absolutely essential for normal development since they provide the growth factors necessary for patterning the limb. These signaling centers are: the AER, the zone of polarizing activity (ZPA) and the non-AER ectoderm. The AER is the specialized thickened ectoderm rimming the distal edge of the limb bud and is required for proximal-distal elongation (Fig. 1D, 1E). The ZPA is a group of mesodermal cells located at the posterior border of the bud that controls patterning along the anterior-posterior axis. Finally, the non-AER ectoderm directs pattern formation in the dorsal-ventral (DV) axis. Recent studies have emphasized that the function of these signaling centers is interdependent and that adequate interactions between them are absolutely essential for a morphologically correct limb to develop (Laufer et al., 1994; Niswander et al., 1994; Parr and McMahon, 1995; Yang and Niswander, 1995). An example of this is the complex feedback loop established between FGFs expressed in the AER and SHH expressed in the ZPA, which ensures proper limb patterning (Laufer et al., 1994; Niswander et al., 1994). Thus, limb development is controlled by multiple cell-cell interactions and among them the interactions between the mesenchyme and the ectoderm are particularly relevant.

This review will restrict itself to considering only the function of the AER in the proximo-distal organization of the limb bud, primarily based on data obtained from chick and mouse developing limbs.

\section{AER morphology}

The AER is usually defined as the thickened epithelium rimming the distal tip of the growing limb. The well-established AER is a strip of pseudostratified columnar epithelium in the chick and polystratified epithelium in the mouse, covered by the overlying periderm, which runs along the distal DV border of the limb bud (Fig. 2). However, it is important to take into consideration that the AER is a very dynamic structure constantly undergoing morphogenetic changes.

The dynamics of AER morphology were well studied in the chick limb bud (Todt and Fallon, 1984; 1986). In the wing bud, the AER becomes anatomically distinguishable at late stage $18 \mathrm{HH}$ when the distal ectodermal cells of the bud acquire a columnar shape that makes them distinct from the rest of the cuboidal ectoderm. It is only at stage $20 \mathrm{HH}$ that the AER adopts the structure of a pseudostratified epithelium that is maintained at later stages (Fig. $1 \mathrm{D}$ and $2 \mathrm{~A}$ ). From stage $23-24 \mathrm{HH}$ the height of the AER progressively decreases (compare Fig. 1D and Fig. 1E) until it eventually regresses at the time the last phalanges are laid down. This occurs between stages 33-35HH in the chick leg (Patou, 1978). During the period of its maximum height, a groove is visible at the base of the chick AER (Todt and Fallon, 1984).

The mouse AER is an equally dynamic structure. The ventral ectoderm of the emerging E9.5 forelimb is already thicker than the dorsal ectoderm and corresponds to the early AER (Bell et al., 1998; Loomis et al., 1998). By E10 this thickening is more pronounced since the epithelium is now bilayered and has become 

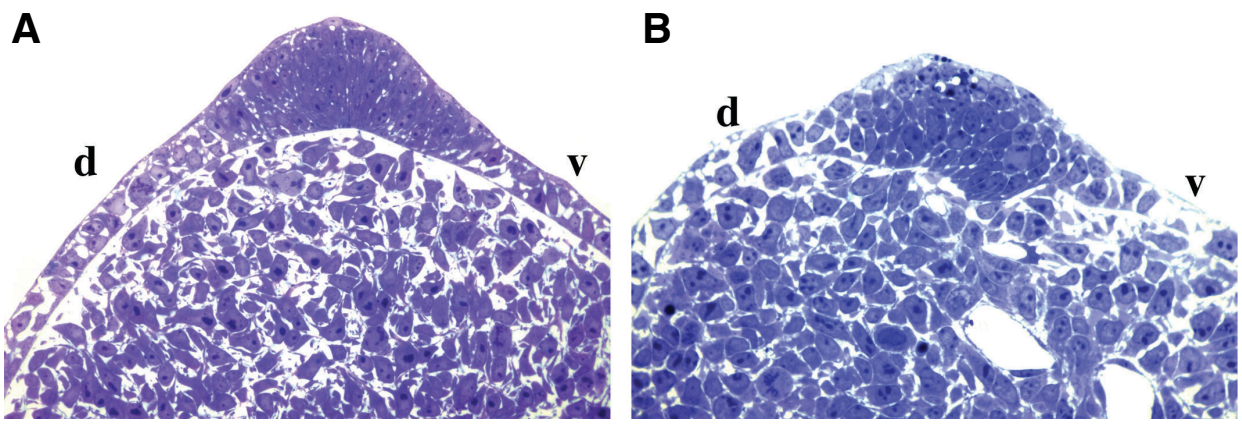

Fig. 2. Morphology of the Apical Ectodermal Ridge (AER). Semithin sections through the distal tip of a stage $20 \mathrm{HH}$ chick wing bud (A) and a mouse E10.5 forelimb (B). Note the pseudostratified epithelium of the chick AER versus the polystratified epithelium of the mouse AER. Note also the periderm layer. Mitosis and cell death can be observed in the mouse AER. The dorsal (d) and ventral (v) sides of the limb are marked.

confined to the ventro-distal margin of the bud although it is not discernible in living specimens or by scanning electron microscopy (SEM; Wanek et al., 1989). By E10.5-11, corresponding to stage 3 of Wanek et al. (1989), a linear and compact AER with a polystratified epithelial structure (3-4 layers) has formed and positioned itself at the distal DV border of the bud (Fig. 2B; Kelley and Fallon, 1983; Meyer et al., 1997; Bell et al., 1998). The notch observed at the base of the avian AER is never observed in the mammalian ridge (Kelley, 1973). It is worth mentioning that the structure of the human AER is more similar to that of the mouse (Milaire, 1965).

The term "mature AER" denotes a linear compacted band of pseudostratified (bird) or polystratified (mammal) epithelium running along the distal tip of the bud. Previous stages in AER development, when its mature morphology has not yet been established, are normally referred to as "pre-AER" (Loomis et al., 1998; Kimmel et al., 2000). It is worth noting that both in chick and mouse, a mature AER is not formed until relatively late, about 24 hours after the initial budding of the limb. Indeed, in the mouse, the typical elevation of the mature AER is not detectable by SEM until E11 (Wanek et al., 1989). After reaching its maximal elevation, the AER begins to flatten, eventually becoming morphologically indistinguishable from the dorsal and ventral ectoderm. This process of progressive flattening of the AER is referred to as "AER regression" and occurs first over the interdigital spaces then over the digits (Jurand, 1965; Milaire, 1974; Wanek et al., 1989; Guo et al., 2003). Remarkably, genetic cell lineage analysis in the mouse has shown that no descendents of AER cells are detectable at birth indicating that the AER is an embryonic transitory structure (Guo et al., 2003). This contrasts with other signaling centers of the limb bud such as the ZPA, whose descendents contribute to more than half of the autopod (Harfe et al., 2004).

Despite the elaborated structural organization of the mature $A E R$, it is known that it is not required for its function. The first evidence in this direction came from early experiments performed by Saunders and co-workers, showing that an ectodermal hull that had been reversed inside out could still accomplish a perfect function (Errick and Saunders, 1974). These investigators also dissected, dissociated and re-aggregated AER cells to demonstrate that after this process they were still capable of directing normal outgrowth and patterning (Errick and Saunders, 1976). An intriguing question, then, is why the AER adopts its typical morphol- ogy. The observation that highly prominent AERs associate temporally and spatially with intense mesodermal growth, suggests that the pseudo or polystratified morphology may be adopted to pack at the distal tip of the limb a higher number of AER cells, and therefore, focalize a higher production of growth factors. In the chick wing bud for example, the height of the AER varies along its anterior-posterior length; the area of highest elevation associates with the posterior mesoderm where more active growth occurs (Saunders, 1948). Also, the particular morphology of the mature compacted AER may be required to provide an adequate mechanical framework to generate the paddle shape of the limb bud and achieve the refined distal morphology of the limb (Dahmann and Basler, 1999). This notion is supported by the digital malformations, most frequently syndactyly that associate with deficiencies in the process of AER maturation. It is also worth mentioning here that a proper AER morphology is not equivalent to a functional $A E R$, as we will discuss below.

Inherent with normal AER development is the presence of apoptotic cells (Fig. 3A). Both in chick and mouse limb buds, apoptotic cell death is always observed within the AER all along its life span (Jurand 1965; Todt and Fallon 1984; Fernandez-Teran et al., 2006). Dying cells are uniformly distributed all along the anterior-posterior extension of the AER, except during the early stages of the chick wing development, when cell death preferentially localizes to the anterior part of the AER (Todt and Fallon, 1984; Fernandez-Teran et al., 2006). Curiously, cell death was never observed in the non-AER ectoderm while mitosis occurred similarly in AER and non-AER ectoderm (Fernandez-Teran et al., 2006) (Fig. 3). Therefore, whilst mitosis and apoptosis are con-
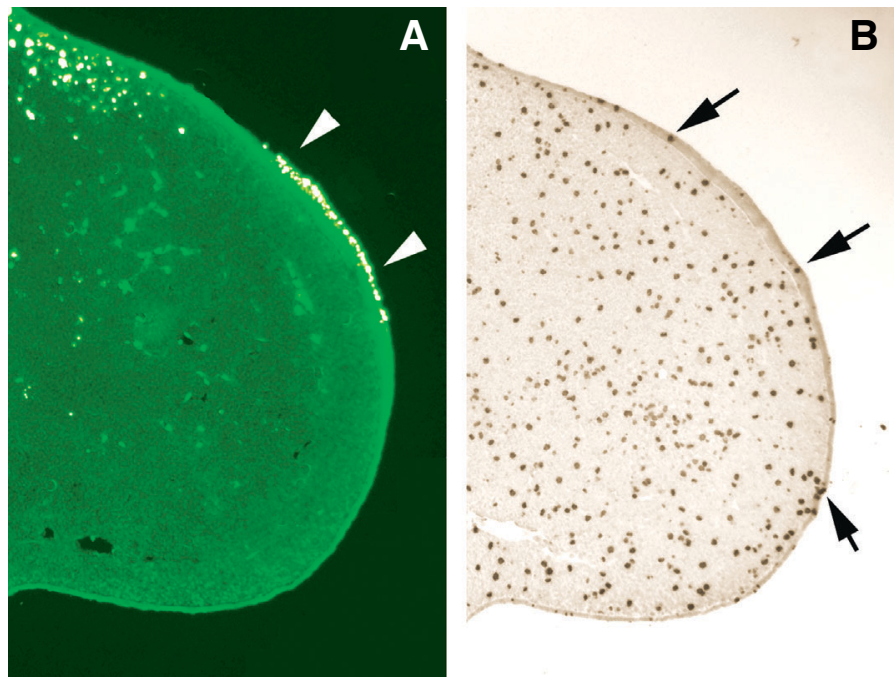

Fig. 3. Cell death and cell proliferation in the AER of stage $23 \mathrm{HH}$ chick wing. (A) Frontal section through the middle of the bud assayed for cell death by TUNEL showing intense cell death in the AER (arrow heads). (B) Consecutive section assayed for cell proliferation with the anti-phosphorylated histone $\mathrm{H} 3$ antibody showing mitotic cells in the AER (arrows). 
comitantly observed in the AER, only cell proliferation but not cell death occurs in the non-AER ectoderm (Fernandez-Teran et al., 2006).

Although the meaning of cell death in the AER is not yet clear, several observations indicate that it contributes to the control of the number of AER cells. For example, a substantial decrease in the number of apoptotic cells within the AER correlates with polydactylous phenotypes that are, therefore, interpreted as resulting from enhanced AER activity (Hinchliffe and Ede, 1967; Dvorak and Fallon, 1991; Bose et al., 2002). Very interestingly, the Notch signaling pathway has been involved in the control of the apoptosis within the AER (Francis et al., 2005). Reciprocally, excess of cell death in the AER leads to loss of AER cells as occurs in the Dactylaplasiamutation in mouse, in which the central portion of the AER regresses leading to a phenotype similar to the split-hand/ split-foot human malformation (Mills etal., 1999; Sidow etal., 1999; Yang et al., 1999).

\section{AER activity}

The critical role of the AER in limb bud outgrowth was first revealed by experiments in which it was experimentally removed: the limb that resulted was normal up to a certain level beyond which development failed and nothing formed (Saunders, 1948; Summerbell, 1974; Rowe and Fallon, 1982). Very interestingly, the level of truncation correlated with the stage at which the AER was removed: the earlier the removal, the more proximal the level of truncation. These studies, together with studies of cell lineage, supported the notion that the limb skeletal elements were laid down in a proximo-distal sequence with proximal elements beginning differentiation earlier than more distal ones.

To explain the sequential proximo-distal formation of limb elements specifically, Lewis Wolpert and colleagues devised the Progress Zone Model (Summerbell et al., 1973). The model proposes that progressively distal positional information values are specified in a labile region at the tip of the bud called the "progress zone (PZ)". The PZ is the layer of mesoderm, approximately 300 $\mu \mathrm{m}$ wide, that is under AER influence. Unfortunately, there is no good marker of PZ although several, such as MsX1(Yokouchi et al., 1991; Ros etal., 1992), Nmyc(Sawai et al., 1990), S/ug(Ros etal., 1997), and AP2 (Chazaud et al., 1996; Shen et al., 1997), have been suggested. The cells residing within the $\mathrm{PZ}$ are supposed to progressively change their positional value to a more distal one by an autonomous timing mechanism. It has been suggested that this timing mechanism could involve the counting of the number of cell divisions. When, as a consequence of normal growth, a cell egresses the $\mathrm{PZ}$, its positional value is in fact fixed according to the last positional value acquired while in the PZ. Therefore, cells that leave the $P Z$ early differentiate into proximal elements, while cells that remain longer in the PZ make distal elements. This model satisfactorily explains the results obtained after AER removal as well as other experiments including the phocomelia that results after X-ray irradiation of the limb and the effect of thalidomide (Wolpert et al., 1979).

Different kinds of recombination experiments have shown that the AER exerts a permissive function on the underlying mesoderm. The mesodermal component of a limb bud can be separated from its ectodermal hull and recombined with a limb ectoderm of different age, type (fore versus hind) or even a different species (chick versus mouse) and still it will give rise to a normal limb (Rubin and Saunders, 1972; Kuhlman and Niswander, 1997; FernandezTeran et al., 1999). These experiments highlight the equivalence between AERs of different developmental age and origin disregarding the variations in morphology and gene expression (see below) that the AER normally undergoes. However, the abovementioned experiments can also be taken as indicating that the $A E R$ is a very malleable structure that rapidly responds to the mesoderm; an AER transplanted over a non-matching mesoderm (because of developmental age, type of limb, specie, etc.) rapidly modifies its morphology and gene expression to adapt to the new situation (Zwilling, 1956; MR personal results). It should be noted here that recombination experiments mentioned above have only been successful when the mesoderm is of the same (or related e.g. chick/quail) species origin as the host in which it is going to be grafted. For example recombinant limbs with mouse mesoderm and chick ectoderm have not been shown to survive on a chick host.

\section{Gene expression within the AER}

During the 90s, it gradually became known that AER function was mediated by its production of several members of the Fibro-
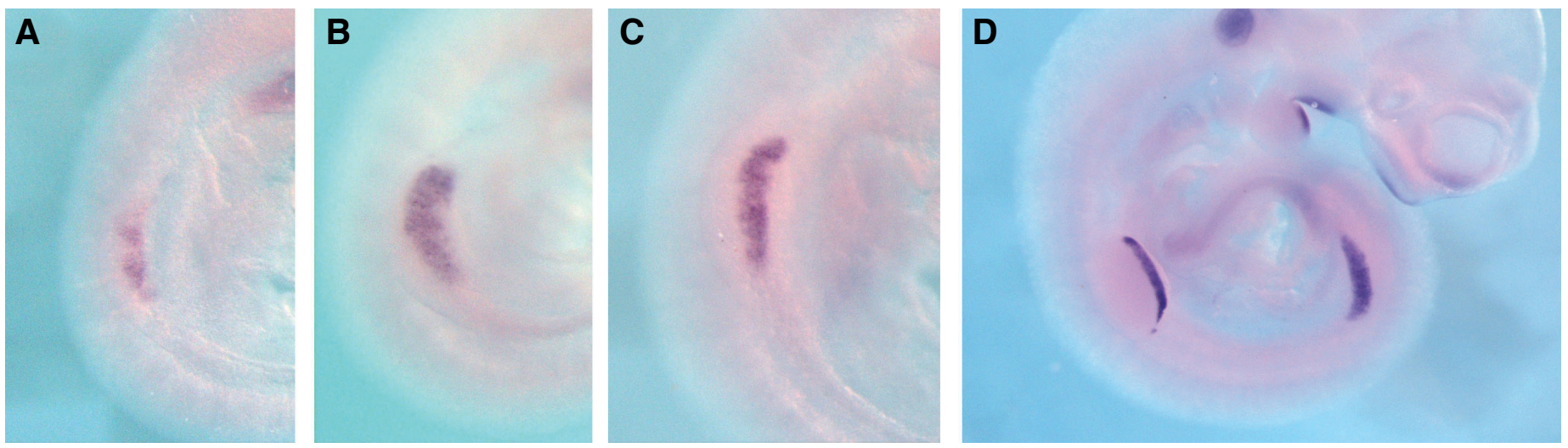

Fig. 4. Fgf8 expression in mouse pre-AER and AER cells. Fgf8 expression is first detected in a patched pattern in the ventral ectoderm of the emerging limb bud (A). From occupying a broad territory (B,C) it progressively becomes confined to the mature AER (D). See text for a more complete description. All the pictures are lateral views of the embryos showing the distal tip of the limb. 

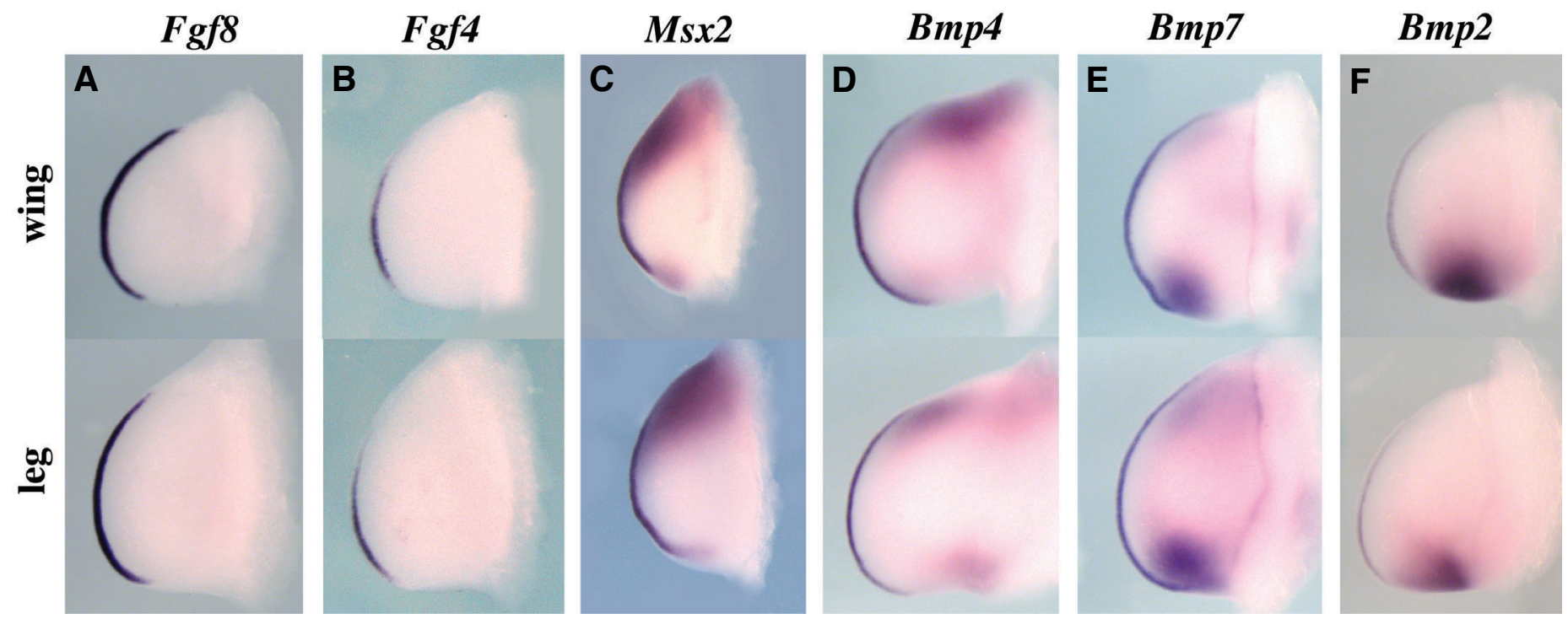

Fig. 5. Expression of $\mathbf{F g f 8 , ~ F g f 4 , ~ M s x 2 , ~ B m p 4 , ~ B m p 7 ~ a n d ~ B m p 2 ~ i n ~ t h e ~ c h i c k ~ l i m b ~ b u d . ~ A l l ~ t h e ~ p a n e l s ~ a r e ~ v e n t r a l ~ p i c t u r e s ~ o f ~ c h i c k ~ w i n g s ~ ( t o p ) ~ a n d ~}$ legs (bottom) stage 22-23HH after hybridization with the specific probe indicated on the top. Note the difference in anterior-posterior extension of the domains of expression.

blast growth factor (Fgfs) family. Four members of this numerous family, Fgf8, Fgf4, Fgfg and Fgf17, show a restricted pattern of expression in the AER during mouse and chick limb development and, accordingly, they are referred to as AER-Fgfs (reviewed in Martin, 1998; Tickle and Munstenberg, 2001). In addition, two other Fgfs are expressed in the chick AER: Fgf2, which is also expressed in the limb ectoderm and underlying mesoderm (Savage et al., 1993; Dono and Zeller, 1994), and Fgf19 (Kurose et al., 2004).

Fgfo expression is detected in the limb surface ectoderm from the earliest stages of limb development $(16 \mathrm{HH}$ in the chick wing and E9 in the mouse forelimb) (Fig. 4), and its expression is considered to mark the precursors of the AER (Martin, 1998; Loomis et al., 1998; Bell et al., 1998). The early Fgf8 domain is patched indicating a mixing of expressing and non-expressing cells but rapidly evolves to a more compact domain encompassing the process of maturation of the AER (Crossley et al., 1996). Fgfo is considered the antonomasia marker of the AER as its expression temporally and spatially accompanies the whole existence of the AER. For this precise reason, Fgf8 expression in the limb ectoderm is considered a synonym of the presence of AER cells. Although, as will be discussed later, a morphological AER does form in the absence of Fgf8, and also in the absence of Fgf8 and Fgf4 (Lewandoski et al., 2000; Moon and Capecchi, 2000; Sun et al., 2002; Boulet et al., 2004).

The temporal discrepancy between the early beginning of Fgf8 expression in the limb ectoderm and the subsequent establishment of the mature AER led to the introduction of the term "preAER" to refer to the cells that express Fgfo but have not yet developed the morphology of the AER (Loomis et al., 1998; Kimmell et al., 2000) (Fig. 4). This discrepancy is at the root of the distinction sometimes made between molecular and morphological AER and reflects the fact that the AER can be defined by either morphological or molecular criteria.

In contrast to Fgf8, the other AER-Fgfs show a much more temporally and spatially restricted pattern of expression. Their expression is detected only after the mature AER has been established, confined to a central-posterior domain and at a much lower level than Fgf8. For example, Fgf4 is expressed only in the posterior-distal part of the AER, over the mesodermal area of greatest growth (Niswander and Martin, 1992; Saunders 1948) (Fig. 5A-B). Interestingly, the expression of Fgf4 in the AER is regulated by FGF8, since, in the absence of Fgf8 it becomes temporally and spatially upregulated (Moon and Capecchi, 2000; Lewandoski et al., 2000).

The proof that FGFs were responsible for AER function came from experiments showing that several FGFs could act as substitutes for the AER (Niswander et al., 1993; Fallon et al., 1994). An exogenous source of FGF applied to the distal limb mesoderm immediately after the removal of the AER was capable of sustaining further elongation of the bud and the development of a close to normal limb. The exogenously applied FGF also prevented the cell death that normally occurs after AER removal and maintained normal gene expression in the underlying mesoderm (Rowe etal., 1982; Fallon et al., 1994). Therefore, the AER-FGFs provide proliferation/survival factors for the underlying mesoderm that allow normal progression of limb development. Of particular relevance was the finding that several FGFs were even capable of inducing a supernumerary limb when ectopically applied to the flank interlimb region in chick embryos (Cohn et al., 1995). In the mouse, chimeras containing Fgf4-expressing cells show small ectopic outgrowths in the flank and application of FGF4 beads to the flank region of mouse embryos in vitro induces the formation of ectopic limb buds (Abud et al., 1996; Tanaka et al., 2000).

Besides Fgfs, a growing number of genes are known to be expressed in the AER (Fig. 5). These include transcription factors such as En1 (Loomis et al., 1996), D/x2, 5 and 6 (Bulfone et al., 1993; Robledo et al., 2002; Kraus and Lufkin, 2006), Msx2 (Davidson et al., 1991), and Sp8, Sp9 and Sp6 (Treichel et al., 2003; Bell et al., 2003; Nakamura et al., 2004); components of signaling pathways such as Bmp2, 4 and 7 (Francis et al., 1994; Lyons et al., 1995) Wnt3a/Wnt3(Kengaku et al., 1998; Barrow et al., 2003), Notch1, Jag2 and Rfng (Radical fringe; Laufer et al., 
1997, Rodriguez-Esteban et al., 1997; Sidow et al., 1997; Jiang et al., 1998); the transmembrane protein Flrt3 (Smith and Tickle, 2006) and several epithelial markers such as $C d 44$ (Wheatley et al., 1993), the connexin Cx43 (Laird et al., 1992), and p63 (Mills et al., 1999; Yang etal., 1999). Several of these mentioned genes are specifically expressed in the AER and can also be considered AER markers (Bell et al., 1998) but others, such as En1, Msx2, Bmps, Sp8, Sp9and Sp6exhibit ectodermal domains of expression broader than that of Fgf8. Particularly interesting is the pattern of expression of En1 (Engrailed1), a homeodomain containing transcription factor, which is expressed precisely in the ventral half of the AER and ventral limb ectoderm (Gardner and Barald, 1992) and is required for the maturation of the AER (see below). For the genes that are expressed in the AER, a comprehensive study to provide a precise definition, in both temporal and spatial terms, of their domains of expression within the AER, and which is yet to appear, would be very useful.

\section{Genetic removal of FGFs from the AER}

To prove that FGFs are indeed mediating AER function, the genetic approach of removing one or several AER-Fgfs from the mouse AER has been undertaken. Since Fgf8 and Fgf4 are required at gastrulation, their ablation from the limb bud $A E R$ was performed by using different AER or limb-specific Cre recombinase expression lines. The phenotypes of these experiments showed that Fgfowas the only essential AER-Fgf required for normal limb development (Lewandoski et al., 2000; Moon and Capecchi, 2000), while Fgf4, Fgf9 or Fgf17 were individually or even conjointly dispensable (Moon et al., 2000; Sun et al., 2000; Colvin et al., 2001; Xu et al., 2000). These experiments also showed that Fgf8 in some way repressed Fgf4, since Fgf4 expression was in fact extended, both temporally and spatially upon deletion of $F g f 8$, as we have already mentioned. Remarkably, the simultaneous genetic disruption from the limb ectoderm of Fgf8 and Fgf4, the two AER-Fgfs with the strongest expression in the AER, led to limbless embryos, indicating that FGF8 together with FGF4 represent the principal supply of FGFs from the AER and clearly proving that FGFs are the factors that mediate AER function (Sun et al., 2002; Boulet et al., 2004).

It is interesting to consider the phenotype of the single deletion of Fgf8from the AER (Moon and Capecchi, 2000; Lewandoski et al., 2000; Boulet et al., 2004). The limb that forms in the absence of the AER-Fgf8consistently lacks the radius and first digit and, frequently, digit 2 and the humerus were also absent. As already stated, the upregulation in Fgf4 expression subsequent to the absence of Fgf8could, at least partially, compensate for absence of Fgf8; the phenotype probably depending on the spatial and temporal particularities of this substitution.

In line with this observation, the substitution of Fgf4for Fgf8 in the AER by concomitantly activating a conditional Fgf4 gain-offunction allele and inactivating an Fgfoloss-of-function allele in the same cells, demonstrated that FGF4 could functionally replace FGF8 (Lu et al., 2006). The current model assumes that a certain amount of AER-FGF is required at each stage of limb development, and that the contribution made by the different AER-FGFs is functionally similar (Lu et al., 2006).

A very interesting phenotype is obtained when both Fgf8 and Fgf4 are deleted with the use of the Mxs2-cre line from the forelimb (Sun et al., 2002). Due to the kinetics of Fgf8 and Msx2 expression, these forelimbs develop with a transitory initial expression of Fgf8and only momentary initiation of Fgf4expression. The PZ model predicts that these limbs should become truncated at some point in the stylopod/zeugopod but, however, the three limb segments form, albeit hypoplastic.

The difficulties of the PZ model to satisfactorily explain some of the AER-FGFs phenotypes, as well as data obtained from celllabeling experiments and grafting recombination experiments, lead to the elaboration of another model called the "Early Specification Model" (Dudley et al., 2002). This model proposes that the precursors of the three main segments of the limb are already specified from the earliest stages of limb development. The extensive apoptosis or reduced proliferation that occurs after removal of the AER depending on the stage at which the surgery is performed (Rowe et al., 1982; Dudley et al., 2002), is sufficient to explain the resulting truncation phenotype, without the requirement of a PZ (Dudley et al., 2002). Although both models can satisfactorily explain most of the limb phenotypes resulting from experimental manipulations or from spontaneous or induced mutations, neither model corresponds with the available molecular data (Tabin and Wolpert, 2007). Indeed, other alternative frameworks to interpret proximo-distal patterning are possible, such as the antagonism between distal (FGFs) and proximal (Retinoic acid) signals in controlling the expression of genes with proximo-distal identity (Mercader et al., 2000; Tabin and Wolpert, 2007).

\section{Developmental dynamics of the AER}

Three main phases can be considered over the life span of the AER: the first phase or pre-AER that starts with the specification of the AER precursor cells, a middle phase in which the mature AER is well established and a final phase in which the AER flattens and regresses. These three phases will be considered in the following sections.

\section{AER induction}

Early grafting and recombination experiments in chicks showed that the AER is induced by the underlying mesoderm. The capacity to induce an AER is normally restricted to the presumptive limb mesoderm as well as the capacity to form an AER is restricted to the limb ectoderm and both capacities are temporally regulated (Kieny 1960; 1968; Saunders and Reuss, 1974; Carrington and Fallon, 1984; 1986). The flank (interlimb) ectoderm also has the capacity to form an AER if provided with appropriate signals (Saunders and Reuss, 1974; Carrington and Fallon, 1984; Cohn et al., 1995). Curiously, the dorsal median ectoderm over the neural tube also retains the capacity to form an AER, probably as a vestige of an ancestral dorsal fin (YoneiTamura et al., 1999). In contrast, the neck is limb-incompetent, not due to the presence of specific inhibitors but rather to the loss of key components of the signaling cascades required (Lours and Dietrich, 2005).

Recent research has made it possible to assign the molecular signals intervening in these interactions (Fig. 6). It is known that the induction of the AER is directed by complex interactions between the FGF, WNT/ $\beta$-catenin and BMP signaling pathways that operate within the ectoderm and between the mesoderm and 
ectoderm of the prospective limb bud. It has been demonstrated that WNT/ $\beta$-catenin signaling in the limb ectoderm is necessary and sufficient to induce Fgf8 expression and, therefore, an AER both in chick and mouse (Kengaku et al., 1998; Galceran et al., 1999; Pinson et al., 2000; Kawakami et al., 2001; Soshnikova et al., 2003; Barrow et al., 2003) (Fig. 6). The difference between these two species resides in the particular ligand that activates the canonical WNT pathway that, in the chick, is a particular variant of WNT3a (Narita et al., 2005; 2007), and in the mouse is WNT3 (Barrow et al., 2003). In humans, the ligand that fulfills this role appears to be WNT3 since a spontaneous mutation of Wnt3 results in tetra-amelia (Niemann et al., 2004). WNT family members share with FGFs the spectacular property of inducing additional limbs when applied to the interlimb region (Kawakami et al., 2001).

Chick Wnt3a is initially expressed in a wide area of ectoderm but it becomes quickly restricted to the AER (Kengaku et al., 1998). In contrast, mouse Wnt3 expression occurs in the entire ectoderm of the limb bud but, for AER formation, WNT3 signaling is only required in the ventral ectoderm, the site in which the AER is specified (Barrow et al., 2003). Nevertheless, at least in the chick, the dorsal ectoderm is capable of responding to ectopic WNT3A signaling with the formation of ectopic AERs (Kengaku et al., 1998).

BMP signaling is also essential for the induction of the AER as revealed by loss and gain-of-function experiments, besides being both necessary and sufficient to regulate En1 expression in the ventral ectoderm (Fig. 6) (Ahn et al., 2001; Pizette et al., 2001; Barrow et al., 2003; Soshnikova et al., 2003). Loss of Bmp signaling from the limb bud ectoderm results in failure of AER formation and bidorsal limbs (Ahn et al., 2001; Pizette et al., 2001;). It has been proposed that BMP signaling independently controls AER induction and DV patterning; AER induction is mediated by the MSX transcription factors while control of DV patterning is mediated by EN1 (Pizette et al., 2001).

To analyze the epistatic relationships between the BMP and the WNT signaling pathways in AER induction, compound mutants carrying loss-of-function of the Bmp receptor $1 A(B m p r 1 A)$ gene and gain-of-function mutation in $\beta$-catenin in the limb ectoderm were performed (Soshnikova etal., 2003). Interestingly, the double mutants showed that $\beta$ CATENIN was capable of rescuing the Bmpr1AAER (but not the DV) defective phenotype, indicating that canonical WNT signaling is positioned downstream of BMP signaling in the process of AER induction (Shosnikova et al., 2003). The interactions between these pathways are, however, very intricate since WNT/ $\beta$-catenin signaling also induces Bmp2, Bmp4 and $B m p 7$ expression, establishing a positive reinforcing feedback loop between both pathways (Bar-

Fig. 6. Regulatory cascades in AER induction and maintenance. The main gene interactions involved in $A E R$ induction (A) and maintenance (B) are shown. See text for a complete description. Arrows indicate inductions and bars indicate repression. The color code is indicated at the figure bottom.

row et al., 2003; Soshnikova et al., 2003).

These complex molecular interactions result in the induction of the AER precursors in an ample territory of the presumptive limb ectoderm. Quail transplants in the chick showed that the AER precursor cells were located in a broad region of ectoderm covering the whole early limb field mesoderm (Michaud et al., 1997). However, Dil-labeling of groups of ectodermal cells, also in the chick, showed that AER precursors were initially mixed with dorsal and ventral ectoderm cells (Altabef et al., 1997). While both studies show that AER precursors initially occupy a much broader domain compared to later stages, they differ in that in one case (Michaud et al., 1997) only packing of these precursors will be required to form the AER, while in the other (Altabef et al., 1997) some kind of reorganization or migration would be needed to sort out AER precursors from dorsal and ventral ectodermal cells. The reason for this discrepancy is presently unknown.

In the mouse, AER precursors are initially distributed in a broad domain of thickened ectoderm covering the ventral limb (Milaire, 1974; Crossley and Martin, 1995; Bell et al., 1998; Loomis et al., 1998). As already mentioned, initially Fgf8 expression is patched in this territory but soon becomes solid. From E9.5 to E10.5, these cells become compressed and displaced towards the distal tip of the limb by ectodermal morphogenetic movements of the ventral ectoderm, which depend on En 1expression (Loomis et al., 1998). Lineage labeling experiments have shown that not all the cells in this primitive broad domain become incorporated into the AER, but that some of them remain in the ventral ectoderm and do not become part of the mature AER (Kimmel et al., 2000) as also indicated by the cell-labeling studies in chick (Altabef etal., 1997).

As we have already mentioned, the ability to induce an AER resides in the mesoderm. Several studies have shown that FGF10 is likely to be the factor provided by the mesoderm that starts the process of AER induction. Fgf10 is expressed in the
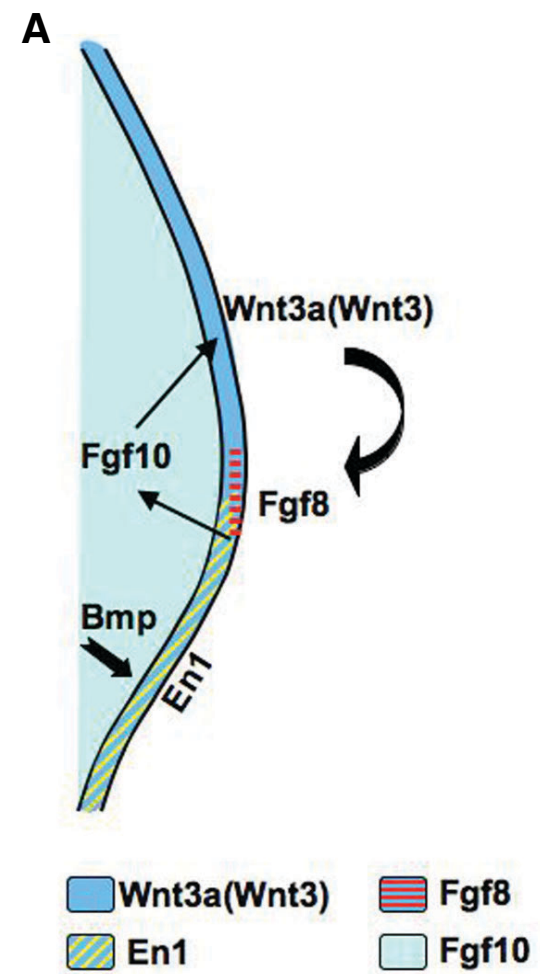
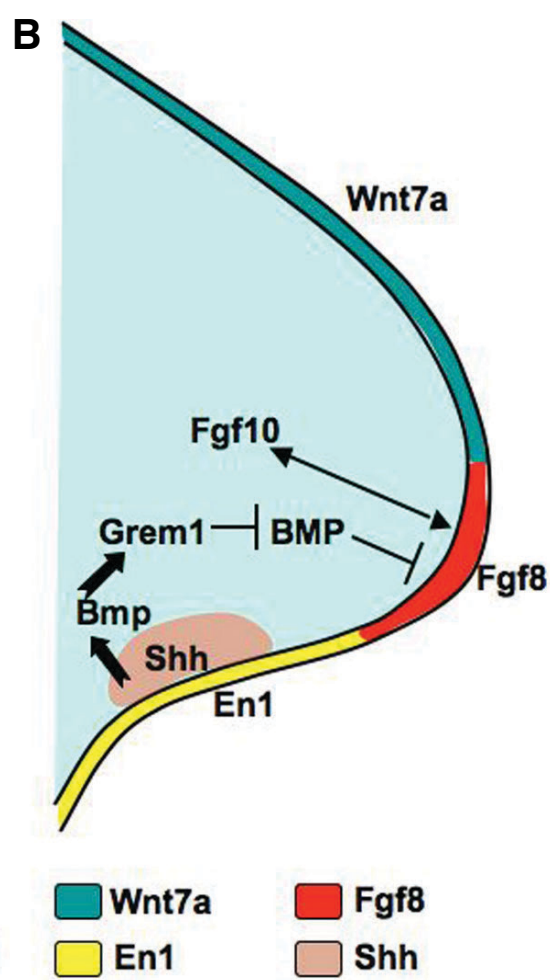

Fgf8

Shh 
lateral plate mesoderm prior to limb emergence (Ohuchi et al., 1997) and its targeted disruption, or that of its receptor Fgfr2b, which is expressed in the overlying limb ectoderm, produces amelic embryos in which the AER is not induced and Fgfo expression is never detected in the mutant ectoderm (Min et al., 1998; Sekine et al., 1999; De Moerlooze et al., 2000). Fgf10 signals to the ectoderm to induce Wnt3a in chicks, and Wnt3in mice, which in turn induces Fgf8 expression (Ohuchi et al., 1997; Kawakami et al., 2001). Then, FGF8 from the AER signals to the mesoderm to maintain Fgf10expression (Fig. 6). This Fgf8/Fgf10 regulatory loop underlies the mutual interactions and dependence between the AER and the mesoderm. FGF10 is probably the nexus between limb initiation and AER induction, since it plays an important role in both processes. Interestingly, the Growth arrest-specific1 (Gas 1) gene, a positive component of the SHH signaling cascade (Allen et al., 2007), acts in the mesenchyme to maintain high levels of FGF10 and, therefore, Fgf8 expression in the AER. Gas1 mutants show proliferation defects in the AER and underlying mesenchyme and develop with small autopods (Liu et al., 2002).

While Fgf10 is initially expressed in the entire limb mesoderm, the induction of the AER only occurs at the DV interphase. However, it is known that $A E R$ induction capacity is present in the dorsal limb bud mesoderm through stage $20 \mathrm{HH}$, long after the normal AER has been induced (Carrington and Fallon, 1986). This suggests that during normal limb development a hypothetical factor may repress this capacity, once the normal ridge has been induced, so that no supernumerary AERs form. In this regard, it is worth mentioning that such a repressive function has been proposed for Cux1, a nuclear effector of the Notch signaling pathway, based on its expression pattern in the non-AER ectoderm and detrimental effect of its forced expression in the AER (Tavares et al., 2000). This putative repressive effect may be absent in the eudiplopodia chick mutant, in which an extra AER forms in the dorsal surface of the bud, resulting in supernumerary limb outgrowths (Goetinck, 1964).

Some component of the signaling pathway operating between the mesoderm and the ectoderm to induce the AER has to be disrupted in the spontaneous chick mutant limbless (Ros et al., 1996; Grieshammer et al., 1996). Limbless embryos initiate limb outgrowth but induction of the AER fails and, therefore, the emerging limb bud regresses due to cell death. The mutant defect remains to be identified although it is known that the activation of the WNT canonical pathway is defective in the early limbless limb bud and that Fgf10, although being activated, is not maintained (Lizarraga et al., 1999; McQueeney et al., 2002).

It is known that, in chick embryos, the specific restriction of Fgf10 expression to the prospective limb mesoderm is controlled by WNT/ $\beta$-catenin signaling in the lateral plate mesoderm (Kawakami et al., 2001). In the mouse Tbx genes probably fulfill this function since, so far, no WNT ligand has been detected in the mouse lateral plate mesoderm (Agarwal et al., 2003; Yang, 2003). In the mouse forelimb, TBX5 is probably the factor that activates Fgf10 transcription in the limb mesenchyme, since Tbx5mutants lack Fgf10expression and, furthermore, the Fgf10 promoter contains several TBX5 binding sites
(Rallis et al., 2003; Agarwal et al., 2003). In the hindlimb, this function is performed by TBX4 (Naiche and Papaioannou, 2007).

\section{Dorso ventral boundary formation and AER induction}

During normal development, the AER invariably develops at the DV boundary of the bud (Altabef et al., 1997; Michaud et al., 1997; Tanaka et al., 1997; Kimmel et al., 2000) (Fig. 1). Also, supernumerary limb buds induced by the application of an FGFsoaked bead to the flank consistently form the AER at the appropriate DV position, in the same plane as the normal fore and hindlimb, independently of the position of the bead (Cohn et al., 1995; Altabef et al., 1997). Interestingly, the chick mutants limbless and wingless and the mouse mutant legless associate defects in AER induction or maintenance with defects in DV patterning (Grieshammer et al., 1996; Noramly et al., 1996; Ros et al., 1996; Ohuchi et al., 1997; Bell et al., 1998) supporting the link between the AER and the DV specification of the ectoderm. Similarly, in the double MsX1;Msx2 mutant, the AER is induced and maintained except at the anterior border, the level at which a DV boundary fails to form (Lallemand et al., 2005).

Meinhardt (1983), based on experimental results and theoretical considerations, suggested that a DV boundary in the ectoderm is a necessary condition for AER formation and, along with what is known about compartment boundaries (Dahmann and Basler, 1999), it seems reasonable to assume that the formation of the AER may require the DV compartment boundary. In support of this view is the observation that the ectopic juxtaposition of dorsal and ventral limb ectoderm induces AER formation (Laufer et al., 1997; Tanaka et al., 1997).

In the chick, the use of cell-fate tracers has permitted the identification of two distinct ectodermal compartments, dorsal and ventral, in the presumptive limb ectoderm with the DV boundary coincident with the position of the AER (Altabef et al., 1997). In the mouse, very thorough and elegant studies carried out by the group led by Alex Joyner revealed that AER formation is coordinated by two lineage boundaries, the dorsal and the middle boundaries (Kimmel et al., 2000). The dorsal border is located along the dorsal margin of the pre-AER domain and the middle border along its middle DV extension, within the AER itself. The middle border was also identified in chick in experiments using quail/chick grafts (Michaud et al., 1997). Kimmel et al. (Kimmel et al., 2000) proposed a model for AER formation in which all the AER precursors cells are pulled towards the dorsal margin domain (the zip model) and, in addition, bidirectional pulling toward the middle border generates the elevation of the AER. Importantly, AER morphogenesis and gene expression depend on cellcell interactions at both borders, which are regulated, at least in part, by Wnt7a and En1. Interestingly, the middle boundary is transient and its disappearance has been proposed to contribute to the regression of the AER morphology (Kimmel et al., 2000).

During limb development DV patterning requires complex interactions between the ectoderm and mesoderm (Chen and Johnson, 1999). Before the onset of limb development, DV information is acquired by the prospective limb mesoderm and then this information is transferred to the ectoderm between stages 14 to $16 \mathrm{HH}$ in the chick (MacCabe et al., 1974; Geduspan and MacCabe, 1987). Once DV patterning is established in the ectoderm, then it is the ectoderm that imposes the DV information 
The Apical Ectodermal Ridge
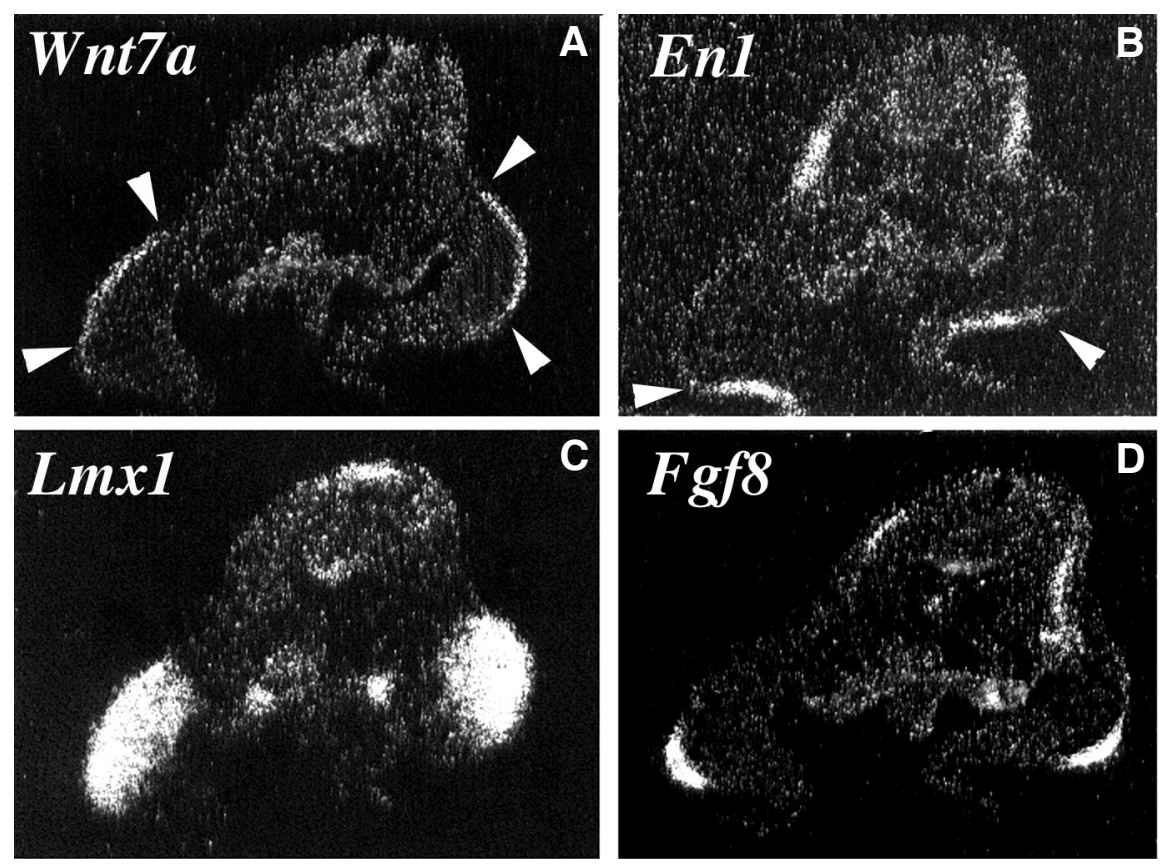

Fig. 7. Expression of Wnt7a, En1, Lmx1b and Fgf8. Dark-field micrographs of in situ hybridization of consecutive cross sections of a stage $18 \mathrm{HH}$ embryo at the level of the wing buds with the probes indicated in each panel. Note that Wnt7a marks the dorsal ectoderm and En1 the ventral ectoderm (arrows in $\mathbf{( A , B ) ~ r e s p e c t i v e l y ) . ~}$

on the mesoderm (Akita, 1996; Michaud et al., 1997; Chen and Johnson, 1999). Experimental manipulations and gain and lossof-function experiments on chicks and genetic studies on mice have demonstrated that BMP signals, probably from the lateral mesoderm, are crucial for DV patterning since they specify the ventral ectoderm by inducing the expression of En1. This occurs in a narrow temporal window immediately prior to the initial outgrowth of the limb bud (Ahn et al., 2001; Pizette et al., 2001). Other unidentified signals from the somitic mesoderm (maybe noggin) dorsalize the overlying ectoderm that is destined to become the dorsal limb ectoderm (Michaud et al., 1997). It is worth mentioning that the gain of function of $\beta$-CATENIN does not rescue the DV defect typical of Bmpr1a mutants, indicating that canonical Wnt signaling acts upstream or parallel to BMP signaling in DV patterning (Shosnikova et al., 2003).

The specification of DV polarity in the ectoderm results in the establishment of specific domains of gene expression. Wnt7a is specifically expressed in the dorsal limb ectoderm (Fig. 7A) and plays an essential role in controlling DV patterning of the limb bud by imposing the expression of $L m \times 1 b$, a LIM homeodomaincontaining gene, in the dorsal mesoderm (Fig. 7C) (Dealy et al., 1993; Parr et al., 1993; Parr and McMahon, 1995; Riddle et al., 1995; Vogel et al., 1995). Ventral limb patterning is controlled by EN1 that, at least in part, acts to confine Wnt7a expression to the dorsal ectoderm.

However, our understanding of the link between AER formation and DV patterning is incomplete since the molecules that establish the ectodermal compartments have not yet been identified. Loss or gain-of-function of Wnt7a or Lmx1b disrupts DV patterning but without affecting the morphogenesis of the AER (Loomis et al., 1998; Kimmel et al., 2000). Also, in the combined loss of function of Wnt7aand En1, AER development is almost normal, indicating that Wnt7a is required for the AER defects of the En1 mutant and also that neither gene is required for the specification of the boundary required for AER formation (Loomis etal., 1998; Kimmel et al., 2000). En1 does not specify the ventral compartment in either chick or mouse but it clearly plays a role in AER development (Logan et al., 1997; Altabef et al., 2000). The observation that either activation or elimination of BMP signaling over the whole limb bud ectoderm similarly leads to failure in the formation of the AER (Pizette et al., 2001), indicates that what may be important for AER formation is the generation of a border of BMP activity. Therefore, it is possible that the establishment of ectodermal compartments and AER formation requires the generation of a sharp boundary of BMP signaling between the prospective ventral and dorsal ectoderm.

\section{AER maturation}

As already stated, specification of AER precursors, both in the chick and in the mouse, occurs in a wide territory over the presumptive limb mesoderm which, particularly in the mouse, occupies the ventral ectoderm (Altabef et al., 1997; Michaud et al., 1997; Kimmel et al., 2000). In a second phase, ectodermal morphogenetic movements displace and compact AER cells over the DV tip of the limb bud resulting in the linear and thickened mature AER (Loomis et al., 1998). This process is usually referred to as maturation of the AER, and is under the control of multiple factors. For example, it is known that En 1 is required for the maturation of the AER since in its absence there is a marked ventral expansion of the anterior half of the AER that gives rise to bifurcated and even secondary AERs (Loomis et al., 1998). Based on these observations, Loomis et al. (1998) have proposed a model for the compaction of the AER that imply morphogenetic movements of the ectoderm that are compared to the closing of a zipper. The two halves of the zipper are the ventral and dorsal halves of the initially broad pre-AER. During the closing process the dorsal half remains fixed while the ventral half is pulled toward the dorsal half in a posterior to anterior direction. Several components of the canonical WNT signaling pathway have also been shown to be involved in AER maturation (see the section of Altered AER morphologies).

Another factor that is required for AER maturation is SP8 since in the $S p 8$ mutant the pre-AER cells are induced, but the ventral ectoderm cells do not compact at the limb apex (Bell et al., 2003; Treichel et al., 2003).

\section{AER maintenance}

Once induced, the AER requires continuous maintenance signals from the limb mesoderm (Zwilling, 1956; Saunders, 1948). As soon as the AER is deprived of signals from the underlying mesoderm, for example by transplantation over non-limb mesoderm, or isolation by a barrier, it flattens and regresses. This was interpreted in the early studies by Saunders and Zwilling as the 
mesoderm producing the Apical Ectodermal Maintenance Factor (AEMF) which, in the chick wing, is more abundant posteriorly than anteriorly (Zwilling, 1956). As a consequence, the AER of the chick wing is asymmetric along its anterior posterior axis; it is much taller posteriorly than anteriorly. When the antero posterior organization of the AER is experimentally reverted, the asymmetry in the AER also reverts rapidly, becoming taller over the posterior mesoderm proving that the AER asymmetry depends on the mesoderm (Zwilling, 1956). It is known that maintenance of the AER requires continuous $W N T / \beta$-catenin signaling in the ectoderm since even the removal of Wnt3 after AER formation results in AER regression (Barrow et al., 2003). Indeed, AER maintenance appears to require a balanced amount of canonical WNT signaling since either an excess of signaling, as in the DKk1 mutant, or a deficit in signaling, as in $\angle r p 6$ mutants, lead to failure in AER maintenance (Pinson et al., 2000; Mukhopadhyay et al., 2001).

Currently, Fgf10 and Gremlin1 are also involved in AEMF activity (Fig. 6). FGF10 is required not only for induction of the AER but also for its maintenance. Interestingly, it has recently been shown that Fgf10 expression in the mesoderm, and thus AER maintenance, depends on the adequate balance between Hoxd genes and Gli3 (Zakany et al., 2007). FGF10-dependent maintenance of the AER could be mediated by the transcription factor SP8. SP8 is a member of the Sp family that is expressed first in the whole limb ectoderm and then in AER cells (Bell et al., 2003; Treichel etal., 2003; Kawakami etal., 2004). In the absence of Sp8, Fgfo expression is initiated in pre-AER cells but rapidly declines and a mature AER fails to form. Since $S p 8$ is positively regulated by Fgf10 (Kawakami et al., 2004), it is possible that it mediates the FGF10-dependent maintenance of the AER. Furthermore, $S p 8$ is likely capable of regulating Fgfo in a direct way since the proximal region of the Fgfo gene has multiple Sp1binding sites (Bouwman and Philipsen, 2002; Kawakami et al., 2004). Two other members of the Sp family, Sp6and Sp9, are also expressed in the limb ectoderm and AER (Kawakami et al., 2004; Nakamura et al., 2004) and could play redundant functions with SP8. Therefore, a complete understanding of the role SP factors play on AER maintenance and possibly induction requires further investigation.

Another factor that participates in the maintenance of Fgf8 expression in the AER is Gremlin1 (Grem1; Zuñiga et al., 1999; Khokha et al., 2003; Zuñiga et al., 2004). Grem1 is a member of the DAN family of BMP antagonists that mediates the positive feed back loop between the FGFs in the AER and SHH in the ZPA (Zuñiga et al., 1999). As we have already stated, during normal limb development, BMP signaling modulates AER function by negatively modulating Fgf8 expression an effect that is antagonized by GREM1 (Gañan et al., 1996; Pizette and Niswander, 1999). Inactivation of Grem 1 results in enhanced BMP signaling in the mesoderm. This perturbs the normal maturation of the AER, which appears flattened and unable to maintain the feedback loop with the ZPA (Khokha et al., 2003; Zuñiga et al., 2004). Interestingly, cell lineage tracing experiments have shown that Shhexpressing descendant cells are unable to express Grem 1 and that this refractoriness is crucial in the eventual termination of the SHH-FGF loop and therefore in the control of limb bud growth (Scherz et al., 2004). Recently, BMP activity has been involved in Grem 1 regulation of expression (Nissin et al., 2006).
In summary, maintenance of the AER requires the positive inputs of WNT and FGF10 signaling from the ectoderm and mesoderm respectively, as well as the blocking of the negative effect of BMPs achieved by GREM1.

\section{Regression of the AER}

Eventually the AER regresses; its particular morphology and gene expression progressively vanish becoming indistinguishable from the dorsal or ventral ectoderm. The regression of the AER is under the control of BMP signaling since overexpression of Noggin, a potent BMP antagonist, leads to abnormal AER persistence both in chick and mouse (Pizette and Niswander, 1999; Guha et al., 2002). Therefore, while BMP signaling is required for the induction of the AER, once induced, BMP signaling is detrimental for the AER and indeed the AER is maintained as far as the BMP signaling is appropriately counterbalanced (see the AER maintenance section).

This dynamic role of BMP signaling: early BMP activity required for $A E R$ formation and later activity required for cessation of AER-FGF expression, has been recently confirmed by the specific deletion of Bmpr1a from pre-AER or from AER cells. If BMP signaling is specifically abolished from the AER, Fgfo expression continues for longer and interdigital apoptosis is blocked without there being any modification of the expression pattern of Bmps in the mesoderm (Wang et al., 2004; PajniUnderwood et al., 2007). This latter result suggests that BMP signaling controls apoptosis in the interdigital areas indirectly through their modulation of FGF signaling from the AER (PajniUnderwood et al., 2007) and very nicely fits with the observation that enhanced FGF signaling from the AER results in severe cutaneous syndactyly without modifying the pattern of Bmp expression in the interdigital mesenchyme (Lu et al., 2006). Interestingly, it seems that the AER can receive BMP signaling directly from the AER itself or from the mesoderm (Gañan et al., 1996; Guha et al., 2002; Wang et al., 2004: Selever et al., 2004; Bandyopadnyay et al., 2007).

Reduction of FGF signaling from the AER by the additional removal of Fgf8 or Fgf4 alleles, in the absence of Bmpr1a, is sufficient to rescue the syndactylous phenotype. This indicates that BMPs normally regulate interdigital cell death through the modulation of AER-FGFs signals, which act as survival factors for the interdigit mesenchyme (Pajni-Underwood et al., 2007). Nevertheless, BMP signaling may also have a more direct role on interdigital cells (Zuzarte-Luis and Hurle, 2005).

Interestingly, the regression of the AER occurs first over the interdigital spaces, the areas with higher level of BMP signaling (Gañan et al., 1996; Pizette and Niswander, 1999).

\section{Altered AER morphologies}

There are a growing number of spontaneous or induced mutations that affect AER development and produce altered morphologies. Abnormal morphologies include hyperplastic, hypoplastic, immature and misaligned AERs. We will now consider some of these altered morphologies.

A hyperplastic AER is thicker than normal and probably results from the assembly of a greater number of cells than normal. Hyperplastic AERs are highly elevated and look prominent, but sometimes may protrude towards the mesoderm. As we have 
mentioned, during normal development, taller AERs associate with areas of high growth. Hyperplastic or broadened AERs have been observed in the cases of reduced BMP signaling due to overexpression of Noggin or loss of Bmp4 expression in the mesoderm (Pizette and Niswander, 1999; Wang et al., 2004; Selever et al., 2004). As we have already stated, after an initial time window in which BMP signaling is required for AER induction and DV patterning, subsequent BMP signaling is detrimental for the $A E R$ and is thought to control normal $A E R$ regression after the limb skeletal elements have been specified (Gañan et al., 1996; Pizette and Niswander, 1999). In general, the reduction of BMP signaling in the AER results in hyperplastic AERs, either elevated or broadened, whereas enhanced BMP signaling results in premature regression of the AER.

Interestingly, the significant reduction in FGF signaling that occurs in the combined genetic ablation of Fgf8and Fgf4from the AER results in a morphologically normal AER but with some areas of abnormal thickness in the forelimb (Sun et al., 2002). This observation indicates that absence of Fgf8 and Fgf4 from the mutant AER does not interfere with AER morphogenesis and also suggests a compensatory mechanism in response to the absence of FGF signaling. It should be noted that double Fgf\&, Fgf4 mutants loose Bmp expression from the mesoderm but not from the AER itself.

Hypoplastic AERs are thinner than normal. $D / x 2, D / x 5$ and $D / x 6$ are expressed in the AER (Bulfone et al., 1993; Robledo et al., 2002) and deletion of any single one of these genes has no phenotypic consequences. However, the simultaneous targeted inactivation of $D / \times 5$ and $D / x 6$ results in a phenocopy of the splithand/split-foot human malformation (SHFM1) because of the premature flattening and regression of the central part of the AER. These two genes appear to play essential and redundant functions for the maintenance of the central part of the AER that in their absence regress earlier than normal (Robledo et al., 2002). This observation has led to the suggestion that $D / x$ genes may normally block BMP function, a hypothesis that needs further investigation. In this regard, $p 63$, the gene responsible for the Dactylaplasia mutation, is also required for the maintenance of the central AER and responsible in humans for the SHFM1 malformation (Mills et al., 1999; Yang et al., 1999; Sidow et al., 1999). P63 appears to be an ectoderm-specific direct target of BMP signaling (Bakkers et al., 2002).

Broad and flat AERs seem to result from a defect in the maturation process and are characteristic of En1 and Dkk1 mutants. In these two mutants the AER is induced but there is a delay or failure in the compaction of AER precursors towards the distal tip that may evolve to a "double ridge" morphology. The morphology of the double ridge consists of a DV thickened domain of Fgf8 expression outlined by two parallel borders that are more prominent and show more intense Fgfoexpression. This morphology may even lead to two parallel and independent stripes of Fgf8expression being formed. These two parallel ridges could go on to promote either independent digit outgrowth or partial distal digit duplications. The doubleridge mutation, socalled because of the AER morphology, is caused by a hypomorphic allele of $D k k 1$ that results in polysyndactyly (Adamska et al., 2003; 2004). The targeted null allele of Dkk1 (Mukhopadhyay et al., 2001) presents a more severe phenotype of digit fusions and duplications. Because $D k k 1$ is a negative regulator of WNT signaling that has a very dynamic domain of expression including the AER, the double ridge phenotype has been associated with enhanced canonical WNT signaling. In this regard, reduced or complete loss of Lrp4 (Johnson et al., 2005; Simon-Chazottes et al., 2006; Weatherbee et al., 2006), which also results in excessive canonical WNT signaling (Johnson et al., 2005; Weatherbee et al., 2006), produces phenotypes that are very similar to $D k k 1$ mutants. Furthermore, the Dkk1 phenotype was corrected by reduced expression of $L r p 6$ receptor (MacDonald et al., 2004). Syndactyly and polydactyly appear to be secondary to the DV expansion of the hyperplastic AER. The double ridge phenotype can also be considered as a hyperplastic AER.

Modifications of the Notch signaling pathway in the limb bud also result in hyperplastic AER morphologies. Both Notch1 and Jag2 are expressed in the AER and the conditional removal of Notch1from the AER, or the disruption of Jagged2, results in very similar phenotypes consisting in moderate DV expansion of the AER that protrudes into the mesoderm instead of acquiring the elevated normal morphology (Francis et al., 2005; Pan et al., 2005; Sidow et al., 1997; Jiang et al., 1998). It has been shown that the hyperplastic AER morphology results from reduced apoptosis in the AER, therefore involving Notch signaling in the control of cell number in the AER probably through an apoptotic mechanism (Francis et al., 2005).

\section{Summary}

The data summarized in this review clearly demonstrates that the AER is a very dynamic structure, which is continuously undergoing morphogenetic and molecular changes, and is subject to continuous regulation by several regulatory pathways that are sometimes interconnected. One of the most amazing observations is that the AER consistently forms at the dorso-ventral boundary, notwithstanding that the identification of the molecules involved in the generation of this interphase, which might involve BMP signaling, require further investigation.

\section{Acknowledgements}

This work was supported by grant BFU2005-09309-CO2-01 from the Spanish Ministry of Education and Science. We thank the members of our laboratory group for stimulating discussions, and specially $M^{a}$ Felix Bastida for critical reading of the manuscript. We also thank Irene Delgado for Fig. 5 and Marisa Junco for excellent technical help. We are very grateful to Prof. J.M. Icardo and Borja Gallardo for help with the SEM images.

\section{References}

ABUD, H.E., SKINNER, J.A., MCDONALD, F.J., BEDFORD, M.T., LONAI, P. and HEATH, J.K. (1996). Ectopic expression of Fgf-4 in chimeric mouse embryos induces the expression of early markers of limb development in the lateral ridge. Dev Genet. 19, 51-65.

ADAMSKA, M., MACDONALD, B.T. and MEISLER, M.H. (2003). Doubleridge, a mouse mutant with defective compaction of the apical ectodermal ridge and normal dorsal-ventral patterning of the limb. Dev Biol. 255, 350-362.

ADAMSKA, M., MACDONALD, B.T., SARMAST, Z.H., OLIVER, E.R. and MEISLER, M.H. (2004). En1 and Wnt7a interact with Dkk1 during limb development in the mouse. Dev Biol. 272, 134-44.

AGARWAL, P., WYLIE, J.N., GALCERAN, J., ARKHITKO, O., LI, C., DENG, C., GROSSCHEDL, R. and BRUNEAU, B.G. (2003). Tbx5 is essential for forelimb bud initiation following patterning of the limb field in the mouse embryo. 
Development. 130, 623-633.

AHN, K., MISHINA, Y., HANKS, M.C., BEHRINGER, R.R. and CRENSHAW, E.B. (2001). BMPR-IA signaling is required for the formation of the apical ectodermal ridge and dorso-ventral patterning of the limb. Development. 128, 4449-4461.

AKITA, K. (1996). The effect of the ectoderm on the dorsoventral pattern of epidermis, muscles and joints in the developing chick leg: a new model. Anat Embryol. 193, 377-386.

ALLEN, B.L., TENZEN.T. and MCMAHON, A.P. (2007). The Hedgehog-binding proteins Gas1 and Cdo cooperate to positively regulate Shh signaling during mouse development. Genes Dev. 21, 1244-1257.

ALTABEF, M., CLARKE, J.D. and TICKLE, C. (1997). Dorso-ventral ectodermal compartments and origin of apical ectodermal ridge in developing chick limb. Development. 124, 4547-4556.

ALTABEF, M., LOGAN, C., TICKLE, C. and LUMSDEN, A. (2000). Engrailed-1 misexpression in chick embryos prevents apical ridge formation but preserves segregation of dorsal and ventral ectodermal compartments. Dev Biol. 222, 307-16.

BANDYOPADHYAY, A., KUNIKAZU, T., COX, K., HARFE, B.D., ROSEN, V. and TABIN, C.J. (2007). Genetic analysis of the roles of BMP2, BMP4 and BMP7 in limb patterning and skeletogenesis. Plos Genetics. 2, 2116-2130.

BAKKERS, J., HILD, M., KRAMER, C., FURUTANI-SEIKI, M. and HAMMERSCHMIDT, M. (2002). Zebrafish DeltaNp63 is a direct target of Bmp signalling and encodes a transcriptional repressor blocking neural specification in the ventral ectoderm. Dev Biol. 2, 617-627.

BARROW, J.R., THOMAS, K.R., BOUSSADIA-ZAHUI, O., MOORE, R., KEMLER, R., CAPECCHI, M.R. and MCMAHON, A.P. (2003). Ectodermal Wnt3a/betacatenin signaling is required for the establishment and maintenance of the apical ectodermal ridge. Genes Dev. 17, 394-409.

BELL, S.M., SCHREINER, C.M. and SCOTT, W.J. (1998). The loss of ventral ectoderm identity correlates with the inability to form an AER in the legless hindlimb bud. Mech Dev. 74, 41-50.

BELL, S.M., SCHREINER, C.M., WACLAW, R.R., CAMPBELL, K., POTTER, S.S. and SCOTT, W.J. (2003). Sp8 is crucial for limb outgrowth and neuropore closure. Proc Natl Acad Sci USA. 100, 12195-12200.

BOSE, J., GROTEWOLD, L. and RUTHER, U. (2002). Pallister-Hall syndrome phenotype in mice mutant for Gli3. Hum Mol Genet. 11, 1129-1135.

BOULET, A.M., MOON, A.M., ARENKIEL, B.R. and CAPECCHI, M.R. (2004). The roles of Fgf4 and Fgf8 in limb bud initiation and outgrowth. Dev Biol. 273, 361372.

BOUWMAN, P. and PHILIPSEN, S. (2002). Regulation of the activity of Sp1-related transcription factors. Mol. Cell. Endocrinol. 195, 27-38.

BUlfone, A., KIM, H.J., PUELleS, L., PORTEUS, M.H., GRIPPO, J.F. and RUBENSTEIN, J.L. (1993). The mouse DIx-2 (Tes-1) gene is expressed in spatially restricted domains of the forebrain, face and limbs in midgestation mouse embryos. Mech Dev. 40, 129-140.

CARRINGTON, J.L. and FALLON, J.F. (1984). The stages of flank ectoderm capable of responding to ridge induction in the chick embryo. J Embryol Exp Morphol. 84, 19-34.

CARRINGTON, J.L. and FALLON, J.F. (1986). Experimental manipulation leading to induction of dorsal ectodermal ridges on normal limb buds results in a phenocopy of the Eudiplopodia chick mutant. Dev Biol. 116, 130-137.

CHAZAUD, C., OULAD-ABDELGHANI, M., BOUILLET, P., DECIMO, D., CHAMBON, P. and DOLLE, P. (1996). AP-2.2, a novel gene related to AP-2, is expressed in the forebrain, limbs and face during mouse embryogenesis. Mech Dev. 54, 83-94.

CHEN, H. and JOHNSON, R.L. (1999). Dorsoventral patterning of the vertebrate limb: a process governed by multiple events. Cell Tissue Res. 296, 67-73.

COHN, M.J., IZPISÚA-BELMONTE, J.C., ABUD, H., HEATH, J.K. and TICKLE, C. (1995). Fibroblast growth factors induce additional limb development from the flank of chick embryos. Cell 80, 739-746.

COHN, M.J. and TICKLE, C. (1999). Developmental basis of limblessness and axial patterning in snakes. Nature 6735, 474-479.

COHN, M.J. (2001). Developmental mechanisms of vertebrate limb evolution. Novartis Found Symp. 232, 47-57.

COLVIN, J.S., WHITE, A.C., PRATT, S.J. and ORNITZ, D.M. (2001). Lung hypo- plasia and neonatal death in Fgf9-null mice identify this gene as an essential regulator of lung mesenchyme. Development. 128, 2095-2106.

CROSSLEY, P.H. and MARTIN, G.R. (1995). The mouse Fgf8 gene encodes a family of polypeptides and is expressed in regions that direct outgrowth and patterning in the developing embryo. Development. 121, 439-451.

CROSSLEY, P.H., MINOWADA, G., MACARTHUR, C.A. and MARTIN, G.R. (1996). Roles for FGF8 in the induction, initiation, and maintenance of chick limb development. Cell. 84, 127-136.

DAHMANN, C. and BASLER, K. (1999). Compartment boundaries: at the edge of development. Trends Genet. 15, 320-326.

DAVIDSON, D.R., CRAWLEY, A., HILL, R.E. and TICKLE, C. (1991). Positiondependent expression of two related homeobox genes in developing vertebrate limbs. Nature. 352, 429-431.

DEALY, C.N., ROTH, A., FERRARI, D., BROWN, A.M. and KOSHER, R.A. (1993). Wnt-5a and Wnt-7a are expressed in the developing chick limb bud in a manner suggesting roles in pattern formation along the proximodistal and dorsoventral axes. Mech Dev. 43, 175-186.

DE MOERLOOZE, L., SPENCER-DENE, B., REVEST, J., HAJIHOSSEINI, M., ROSEWELL, I. and DICKSON, C. (2000). An important role for the IIlb isoform of fibroblast growth factor receptor 2 (FGFR2) in mesenchymal-epithelial signalling during mouse organogenesis. Development. 127, 483-492.

DONO, R. and ZELLER, R. (1994). Cell-type-specific nuclear translocation of fibroblast growth factor-2 isoforms during chicken kidney and limb morphogenesis. Dev Biol. 163, 338-351.

DUDLEY, A.T., ROS, M.A. and TABIN, C.J. (2002). A re-examination of proximodistal patterning during vertebrate limb development. Nature. 418, 539-544.

DVORAK, L. and FALLON, J.F. (1991). Talpid2 mutant chick limb has anteroposterior polarity and altered patterns of programmed cell death. Anat Rec. 231, 251-260.

ERRICK, J.E. and SAUNDERS, J.W. (1974). Effects of an "inside-out" limb-bud ectoderm on development of the avian limb. Dev Biol. 41, 338-351.

ERRICK, J.E. and SAUNDERS, J.W. (1976). Limb outgrowth in the chick embryo induced by dissociated and reaggregated cells of the apical ectodermal ridge. Dev Biol. 50, 26-34.

FALLON, J.F., LOPEZ, A., ROS, M.A., SAVAGE, M.P., OLWIN, B.B. and SIMANDL, B.K. (1994). FGF-2: apical ectodermal ridge growth signal for chick limb development. Science 264, 104-107.

FERNANDEZ-TERAN, M., PIEDRA, M.E., ROS, M.A. and FALLON, J.F. (1999). The recombinant limb as a model for the study of limb patterning, and its application to muscle development. Cell Tissue Res.296, 121-129.

FERNANDEZ-TERAN, M.A., HINCHLIFFE, J.R. and ROS, M.A. (2006). Birth and death of cells in limb development: a mapping study. Dev Dyn. 235, 2521-2537.

FRANCIS, P.H., RICHARDSON, M.K., BRICKELL, P.M. and TICKLE, C. (1994). Bone morphogenetic proteins and a signalling pathway that controls patterning in the developing chick limb. Development. 120, 209-211.

FRANCIS, J.C., RADTKE, F. and LOGAN, M.P. (2005). Notch1 signals through Jagged2 to regulate apoptosis in the apical ectodermal ridge of the developing limb bud. Dev Dyn. 234, 1006-1015.

GAÑAN, Y., MACÍAS, D., DUTERQUE-COQUILLAUD, M., ROS, M.A. and HURLE, J.M. (1996). Role of TGF betas and BMPs as signals controlling the position of the digits and the areas of interdigital cell death in the developing chick limb autopod. Development 122, 2349-2357.

GALCERAN, J., FARIÑAS, I., DEPEW, M.J., CLEVERS, H. and GROSSCHEDI, R. (1999). Wnt3a-/- like phenotype and limb deficiency in Lef1(-/-) Tcf1(-/-) mice. Genes Dev. 13, 709-717.

GARDNER, C.A. and BARALD, K.F. (1992). Expression patterns of engrailed-like proteins in the chick embryo. Dev Dyn. 193, 370-388.

GEDUSPAN, J.S. and MACCABE, J.A. (1987). The ectodermal control of mesodermal patterns of differentiation in the developing chick wing. Dev Biol. 124, 398408.

GOETINCK, P.F. (1964). Studies on limb morphogenesis. II. Experiments with the polydactylous mutant eudiplopodia. Dev Biol. 10, 71-91.

GRIESHAMMER, U., MINOWADA, G., PISENTI, J.M., ABBOTT, U.K. and MARTIN, G.R. (1996). The chick limbless mutation causes abnormalities in limb bud dorsal-ventral patterning: implications for the mechanism of apical ridge forma- 
tion. Development. 122, 3851-3861.

GUHA, U., GOMES, W.A., LOBAYASHI, T., PESTELL, R.G. and KESSLER, J.A. (2002). In vivo evidence that BMP signaling is necessary for apoptosis in the mouse limb. Dev Biol. 249, 108-120.

GUO, Q., LOOMIS, C. and JOYNER, A.L. (2003). Fate map of mouse ventral limb ectoderm and the apical ectodermal ridge. Dev Biol. 264, 166-178.

HAMBURGER, V. and HAMILTON, H. (1951). A series of normal stages in the development of the chick embryo. J. Morphol. 88, 49-92.

HARFE, B.D., SCHERZ, P.J., NISSIM, S., TIAN, H., MCMAHON, A.P. and TABIN, C.J. (2004). Evidence for an expansion-based temporal Shh gradient in specifying vertebrate digit identities. Cell 118, 517-528.

HINCHLIFFE, R.J. and EDE, D.A. (1967). Limb development in the polydactylous talpid2 mutant of the fowl. J Embryol Exp Morphol. 19, 327-339.

HINCHLIFFE, J. R. and JOHNSON, D. R. (1980). The Development of the Vertebrate Limb (Clarendon, Oxford).

JIANG, R., LAN, Y., CHAPMAN, H.D., SHAWBER, C., NORTON, C.R., SERREZE, D.V., WEINMASTER, G. and GRIDLEY, T. (1998). Defects in limb, craniofacial, and thymic development in Jagged2 mutant mice. Genes Dev. 12, 1046-1057.

JOHNSON, E.B., HAMMER, R.E. and HERZ, J. (2005). Abnormal development of the apical ectodermal ridge and polysyndactyly in Megf7-deficient mice. Hum Mol Genet. 14, 3523-3538.

JURAND, A. (1965). Ultrastructural aspects of early development of the fore-limb buds in the chick and the mouse. Proc R Soc B. 162, 387-405.

KAWAKAMI, Y., CAPDEVILA, J., BUSCHER, D., ITOH, T., RODRÍGUEZ-ESTEBAN, C. and IZPISÚA-BELMONTE, J.C. (2001). Wnt signals control FGF-dependent limb initiation and AER induction in the chick embryo. Cell. 104, 891-900.

KAWAKAMI, Y., ESTEBAN, C.R., MATSUI, T., RODRÍGUEZ-LEÓN, J., KATO, S. and BELMONTE, J.C. (2004). Sp8 and Sp9, two closely related buttonhead-like transcription factors, regulate Fgf8 expression and limb outgrowth in vertebrate embryos. Development. 131, 4763-4774.

KELLEY, R.O. (1973). Fine structure of the apical rim-mesenchyme complex during limb morphogenesis in man. J Embryol exp Morphol. 29, 117-131.

KELLEY, R.O. and FALLON, J.F. (1983). A freeze-fracture and morphometric analysis of gap junctions of limb bud cells: initial studies on a possible mechanism for morphogenetic signalling during development. Prog Clin Biol Res. 110, 119-130.

KENGAKU, M., CAPDEVILA, J., RODRÍGUEZ-ESTEBAN, C., DE LA PENA, J., JOHNSON, R.L., BELMONTE, J.C. and TABIN, C.J. (1998). Distinct WNT pathways regulating AER formation and dorsoventral polarity in the chick limb bud. Science. 280, 1274-1277.

KIENY, M. (1960). Inductive role of the mesoderm in the early differentiation of the limb bud in the chick embryo. J Embryol exp Morphol. 8, 457-467.

KIENY, M. (1968). Variation in the inductive capacity of mesoderm and the competence of ectoderm during primary induction in the chick embryo limb bud. Arch Anat Microsc Morphol Exp. 57, 401-418.

KIMMEL, R.A., TURNBULL, D.H., BLANQUET, V., WURST, W., LOOMIS, C.A. and JOYNER, A.L. (2000). Two lineage boundaries coordinate vertebrate apical ectodermal ridge formation. Genes Dev. 14, 1377-1389.

KHOKHA, M.K., HSU, D., BRUNET, L.J., DIONNE, M.S. and HARLAND, R.M. (2003). Gremlin is the BMP antagonist required for maintenance of Shh and Fgf signals during limb patterning. Nat Genet. 34, 303-307.

KRAUS, P. and LUFKIN, T. (2006). DIx homeobox gene control of mammalian limb and craniofacial development. Am J Med Genet. 140: 1366-1374.

KUHLMAN, J. and NISWANDER, L. (1997). Limb deformity proteins: role in mesodermal induction of the apical ectodermal ridge. Development. 124, 133139.

KUROSE, H., BITO, T., ADACHI, T., SHIMIZU, M., NOJI, S. and OHUCHI, H. (2004). Expression of Fibroblast growth factor 19 (Fgf19) during chicken embryogenesis and eye development, compared with Fgf15 expression in the mouse. Gene Expr Patterns. 4, 687-693.

LAIRD, D.W., YANCEY, S.B., BUGGA, L. and REVEL, J.P. (1992). Connexin expression and gap junction communication compartments in the developing mouse limb. Dev Dyn.195, 153-161.

LALLEMAND, Y., NICOLA, M.A., RAMOS, C., BACH, A., CLOMENT, C.S. and ROBERT, B. (2005). Analysis of Msx1; Msx2 double mutants reveals multiple roles for Msx genes in limb development. Development. 132, 3003-3014.

LAUFER, E., NELSON, C.E., JOHNSON, R.L., MORGAN, B.A. and TABIN, C (1994). Sonic hedgehog and Fgf-4 act through a signaling cascade and feedback loop to integrate growth and patterning of the developing limb bud. Cell. 79, 993-1003.

LAUFER, E., DAHN, R., OROZCO, O.E., YEO, C.Y., PISENTI, J., HENRIQUE, D., ABBOTT, U.K., FALLON, J.F. and TABIN, C. (1997). Expression of Radical fringe in limb-bud ectoderm regulates apical ectodermal ridge formation. $\mathrm{Na}$ ture. 386, 366-373.

LEWANDOSKI, M., SUN, X. and MARTIN, G.R. (2000). Fgf8 signalling from the AER is essential for normal limb development. Nat. Genet. 26, 460-463.

LIU, Y., LIU, C., YAMADA, Y. and FAN, C.M. (2002). Growth arrest specific gene 1 acts as a region-specific mediator of the Fgf10/Fgf8 regulatory loop in the limb. Development. 129, 5289-300.

LIZARRAGA, G., FERRARI, D., KALINOWSKI, M., OHUCHI, H., NOJI, S., KOSHER, R.A. and DEALY, C.N. (1999). FGFR2 signaling in normal and limbless chick limb buds.Dev Genet. 25, 331-338.

LOGAN, C., HORNBRUCH, A., CAMPBELL, I. and LUMSDEN, A. (1997). The role of Engrailed in establishing the dorsoventral axis of the chick limb. Development.124, 2317-2324.

LOOMIS, C.A., HARRIS, E., MICHAUD, J., WURST, W., HANKS, M. and JOYNER, A.L. (1996). The mouse Engrailed-1 gene and ventral limb patterning. Nature. 382, 360-363.

LOOMIS, C.A., KIMMEL, R.A., TONG, C.X., MICHAUD, J. and JOYNER, A.L. (1998). Analysis of the genetic pathway leading to formation of ectopic apical ectodermal ridges in mouse Engrailed-1 mutant limbs. Development 125, 11371148.

LOURS, C. and DIETRICH, S. (2005). The dissociation of the Fgf-feedback loop controls the limbless state of the neck. Development. 132, 5553-5564.

LU, P., MINOWADA, G. and MARTIN, G.R. (2006). Increasing Fgf4 expression in the mouse limb bud causes polysyndactyly and rescues the skeletal defects that result from loss of Fgf8 function. Development. 133, 33-42.

LYONS, K.M., HOGAN, B.L. and ROBERTSON, E.J. (1995). Colocalization of BMP 7 and BMP 2 RNAs suggests that these factors cooperatively mediate tissue interactions during murine development. Mech Dev 50, 71-83

MACCABE, J.A., ERRICK, J. and SAUNDERS, J.W. (1974). Ectodermal control of the dorsoventral axis in the leg bud of the chick embryo. Dev Biol. 39, 69-82.

MACDONALD, B.T., ADAMSKA, M. and MEISLER, M.H. (2004). Hypomorphic expression of $D k k 1$ in the doubleridge mouse: dose dependence and compensatory interactions with Lrp6. Development 131:2543-2552.

MACKEM, S. (2005). In "Cell signaling and Growth Factors in Development". ed. Unsicker K. and Krieglstein K. pp. 523-618. Wiley \& Co.

MARIANI, F.V. and MARTIN, G.R. (2003). Deciphering skeletal patterning: clues from the limb. Nature. 423, 319-325.

MARTIN, G.R. (1998). The roles of FGFs in the early development of vertebrate limbs. Genes Dev. 12, 1571-1586.

MCQUEENEY, K., SOUFER, R., and DEALY, C. N (2002). $\beta$-Catenin-dependent Wnt signaling in apical ectodermal ridge induction and FGF8 expression in normal and limbless mutant chick limbs. Develop. Growth Differ. 44, 315-325.

MEINHARDT, H. (1983). A bootstrap model for the proximodistal pattern formation in vertebrate limbs. J Embryol Exp Morphol. 76, 139-146.

MERCADER, N., LEONARDO, E., PIEDRA, M.E., MARTínEZ, A.C., ROS, M.A and TORRES, M. (2000). Opposing RA and FGF signals control proximodistal vertebrate limb development through regulation of Meis genes. Development. 127, 3961-3970

MEYER, R.A., COHEN, M.F., RECALDE, S., ZAKANY, J., BELL, S.M., SCOTT, W.J. and LO, C.W. (1997). Developmental regulation and asymmetric expression of the gene encoding Cx43 gap junctions in the mouse limb bud. Dev Genet. 21, 290-300.

MICHAUD, J.L., LAPOINTE, F. and LEDOUARIN, N.M. (1997). The dorsoventral polarity of the presumptive limb is determined by signals produced by the somites and by the lateral somatopleure. Development. 124, 1453-1463.

MILAIRE, J. (1965). Aspects of limb morphogenesis in mammals. In:"Organogenesis" (ed. RL DHaan and H Ursprung), pp 283-300. NY: Holt, Rinehart and Winston.

MILAIRE, J. (1974). La morphogenèse des membres. Bull Acad R Med Belg. 129, 
341-361.

MILLS, A.A., ZHENG, B., WANG, X.J., VOGEL, H., ROOP, D.R. and BRADLEY, A. (1999). p63 is a p53 homologue required for limb and epidermal morphogenesis. Nature. 398, 708-713.

MIN, H., DANILENKO, D.M., SCULLY, S.A., BOLON, B., RING, B.D., TARPLEY, J.E,. DEROSE, M. and SIMONET, W.S. (1998). Fgf-10 is requiered for both limb and lung development and exhibits striking functional similarity to Drosophila branchless. Genes Dev. 12, 3156-3161.

MOON, A.M. and CAPECCHI, M.R. (2000). Fgf8 is required for outgrowth and patterning of the limbs. Nat Genet. 26, 455-459.

MOON, A.M., BOULET, A.M. and CAPECCHI, M.R. (2000). Normal limb development in conditional mutants of Fgf4. Development. 127, 989-996.

MUKHOPADHYAY, M., SHTROM, S., RODRÍGUEZ-ESTEBAN, C., CHEN, L., TSUKUI, T., GOMER, L., DORWARD, D.W., GLINKA, A., GRINBERG, A., HUANG, S.P., NIEHRS, C., BELMONTE, J.C. and WETPHAL, H. (2001). Dickkopf1 is required for embryonic head induction and limb morphogenesis in the mouse. Dev Cell. 1, 423-434.

NAICHE, L.A. and PAPAIOANNOU, V.E. (2007). Tbx4 is not required for hindlimb identity or post-bud hindlimb outgrowth. Development.134, 93-103.

NAKAMURA, T., UNDA, F., DE-VEGA, S., VILAXA, A., FUKUMOTO, S., YAMADA, K.M. and YAMADA, Y. (2004). The Kruppel-like factor epiprofin is expressed by epithelium of developing teeth, hair follicles, and limb buds and promotes cell proliferation. J Biol Chem. 279, 626-634.

NARITA, T., SASAOKA, S., UDAGAWA, K., OHYAMA, T., WADA, N., NISHIMATSU, S., TAKADA, S. and NOHNO, T. (2005). Wnt10a is involved in AER formation during chick limb development. Dev Dyn. 233, 282-287.

NARITA, T., NISHIMATSU, S.I., WADA, N. and NOHNO, T. (2007). A Wnt3a variant participates in chick apical ectodermal ridge formation: Distinct biological activities of Wnt3a splice variants in chick limb development. Dev Growth Differ. (in press).

NIEMANN, S., ZHAO, C., PASCU, F., STAHL, U., AULEPP, U., NISWANDER, L., WEBER, J.L. and MÜLLER, U. (2004). Homozygous WNT3 mutation causes tetra-amelia in a large consanguineous family. Am J Hum Genet. 74, 558-563.

NISSIM, S., HASSO, S.M., FALLON, J.F. and TABIN, C.J.(2006). Regulation of Gremlin expression in the posterior limb bud. Dev Biol. 299, 12-21.

NISWANDER, L. and MARTIN, G.R. (1992). Fgf-4 expression during gastrulation, myogenesis, limb and tooth development in the mouse. Development. 114, 755768.

NISWANDER, L., TICKLE, C., VOGEL, A., BOOTH, I. and MARTIN, G.R. (1993). FGF-4 replaces the apical ectodermal ridge and directs outgrowth and patterning of the limb. Cell. 75, 579-587.

NISWANDER, L., JEFFREY, S., MARTIN, G.R. and TICKLE, C. (1994). A positive feedback loop coordinates growth and patterning in the vertebrate limb. Nature 371, 609-613.

NISWANDER, L. (2003). Pattern formation: old models out on a limb. Nat Rev Genet. 4, 133-143.

NORAMLY, S., PISENTI, J., ABBOTT, U. and MORGAN, B. (1996). Gene expression in the limbless mutant: polarized gene expression in the absence of Shh and AER. Dev Biol. 179, 339-346.

OHUCHI, H., NAKAGAWA, T., YAMAMOTO, A., ARAGA, A., OHATA, T., ISHIMARU, Y., YOSHIOKA, H., KUWANA, T., NOHNO, T., YAMASAKI, M., ITOH, N. and NOJI, S. (1997). The mesenchymal factor, FGF10, initiates and maintains the outgrowth of the chick limb bud through interaction with FGF8, an apical ectodermal factor. Development. 124, 2235-2244.

PAJNI-UNDERWOOD, S., WILSON, C.P., ELDER, C., MISHINA, Y. and LEWANDOSKI, M. (2007). BMP signals control limb bud interdigital programmed cell death by regulating FGF signaling. Development. 134,2359-2368.

PAN, Y., LIU, Z., SHEN, J. and KOPAN, R. (2005). Notch1 and 2 cooperate in limb ectoderm to receive an early Jagged2 signal regulating interdigital apoptosis. Dev Biol. 286, 472-482.

PARR, B.A., SHEA, M.J., VASSILEVA, G. and MCMAHON, A.P. (1993). Mouse Wnt genes exhibit discrete domains of expression in the early embryonic CNS and limb buds. Development. 119, 247-261.

PARR, B.A. and MCMAHON, A.P. (1995). Dorsalizing signal Wnt-7a required for normal polarity of D-V and A-P axes of mouse limb. Nature 374, 350-353.
PAUTOU, M.P. (1978). Cessation of activity of the apical ectodermic crest during morphogenesis of the acropod in the chick embryo. Histological analysis. Arch Biol (Liege). 89, 27-66.

PINSON, K.I., BRENNAN, J., MONKLEY, S., AVERY, B.J. and SKARNES, W.C. (2000). An LDL-receptor-related protein mediates Wnt signalling in mice. Nature. 407, 535-538.

PIZETTE, S. and NISWANDER, L. (1999). BMPs negatively regulate structure and function of the limb apical ectodermal ridge. Development. 126, 883-894.

PIZETTE, S., ABATE-SHEN, C. and NISWANDER, L. (2001). BMP controls proximodistal outgrowth, via induction of the apical ectodermal ridge, and dorsoventral patterning in the vertebrate limb. Development. 128, 4463-4474.

RALLIS, C., BRUNEAU, B.G., DEL BUONO, J., SEIDMAN, C.E., SEIDMAN, J.G., NISSIM, S., TABIN, C.J. and LOGAN, M.P. (2003). Tbx5 is required for forelimb bud formation and continued outgrowth. Development 130, 2741-2751.

RIDDLE, R,D., ENSINI, M., NELSON, C., TSUCHIDA, T., JESSELL, T.M. and TABIN, C. (1995). Induction of the LIM homeobox gene Lmx1 by WNT7a establishes dorsoventral pattern in the vertebrate limb. Cell. 83, 631-40.

ROBLEDO, R.F., RAJAN, L., LI, X. and LUFKIN, T. (2002). The DIx5 and DIx6 homeobox genes are essential for craniofacial, axial, and appendicular skeletal development. Genes Dev.16, 1089-1101.

RODRIGUEZ-ESTEBAN, C., SCHWABE, J.W., DE LA PENA, J., FOYS, B., ESHELMAN, B. and BELMONTE, J.C. (1997). Radical fringe positions the apical ectodermal ridge at the dorsoventral boundary of the vertebrate limb. Nature. 386, 360-366. Erratum in: Nature 1997 Aug 28;388(6645):906.

ROS, M.A., LYONS, G., KOSHER, R.A., UPHOLT, W.B., COELHO, C.N. and FALLON, J.F. (1992). Apical ridge dependent and independent mesodermal domains of GHox-7 and GHox-8 expression in chick limb buds. Development. 116, 811-818.

ROS, M.A., LOPEZ-MARTÍNEZ, A., SIMANDL, B.K., RODRÍGUEZ, C., IZPISÚABELMONTE, J.C., DAHN, R. and FALLON, J.F. (1996). The limb field mesoderm determines initial limb bud anteroposterior asymmetry and budding independent of sonic hedgehog or apical ectodermal gene expressions. Development. 122, 2319-1330.

ROS, M.A., SEFTON, M. and NIETO, M.A. (1997). Slug, a zinc finger gene previously implicated in the early patterning of the mesoderm and the neural crest, is also involved in chick limb development. Development. 124, 18211829.

ROWE, D.A. and FALLON, J.F. (1982). The proximodistal determination of skeletal parts in the developing chick leg. J Embryol Exp Morphol. 68, 1-7.

ROWE, D.A., CAIRNS, J.M. and FALLON, J.F. (1982). Spatial and temporal patterns of cell death in limb bud mesoderm after apical ectodermal ridge removal. Dev Biol. 93, 83-91.

RUBIN, L. and SAUNDERS, J.W. (1972). Ectodermal-mesodermal interactions in the growth of limb buds in the chick embryo: constancy and temporal limits of the ectodermal induction. Dev Biol. 28, 94-112.

SAUNDERS, J.W. (1948). The proximo-distal sequence of origin of parts of the chick wing and the role of the ectoderm. J Exp Zool. 108, 363-404.

SAUNDERS, J.W. and REUSS, C. (1974). Inductive and axial properties of prospective wing-bud mesoderm in the chick embryo. Dev. Biol. 38, 41-50.

SAVAGE, M.P., HART, C.E., RILEY, B.B., SASSE, J., OLWIN, B.B. and FALLON, J.F. (1993). Distribution of FGF-2 suggests it has a role in chick limb bud growth. Dev Dyn. 198, 159-170.

SAWAI, S., KATO, K., WAKAMATSU, Y. and KONDOH, H. (1990). Organization and expression of the chicken N-myc gene. Mol Cell Biol. 10, 2017-2026.

SCHERZ, P.J., HARFE, B.D., MCMAHON, A.P. and TABIN, C.J. (2004). The limb bud Shh-Fgf feedback loop is terminated by expansion of former ZPA cells. Science. 305, 396-399.

SEKINE, K., OHUCHI, H., FUJIWARA, M., YAMASAKI, M., YOSHIZAWA, T., SATO, T., YAGISHITA, N., MATSUI, D., KOGA, Y., ITOH, N. and KATO, S. (1999). Fgf10 is essential for limb and lung formation. Nat Genet. 21, 138-141.

SELEVER, J., LIU, W., LU, M.F., BEHRINGER, R.R. and MARTIN, J.F. (2004). Bmp4 in limb bud mesoderm regulates digit pattern by controlling AER development. Dev Biol. 276, 268-279.

SHEN, H., WILKE, T., ASHIQUE, A.M., NARVEY, M., ZERUCHA, T., SAVINO, E., WILLIAMS, T. and RICHMAN, J.M. (1997). Chicken transcription factor AP-2: 
cloning, expression and its role in outgrowth of facial prominences and limb buds. Dev Biol.188, 248-266.

SIDOW, A., BULOTSKY, M.S., KERREBROCK, A.W., BRONSON, R.T., DALY, M.J., REEVE, M.P., HAWKINS, T.L., BIRREN, B.W., JAENISCH, R. and LANDER, E.S. (1997). Serrate2 is disrupted in the mouse limb-development mutant syndactylism. Nature. 389, 722-725.

SIDOW A, BULOTSKY MS, KERREBROCK AW, BIRREN BW, ALTSHULER D, JAENISCH R, JOHNSON KR, and LANDER ES. (1999) A novel member of the F-box/WD40 gene family, encoding dactylin, is disrupted in the mouse dactylaplasia mutant. Nat Genet. 23:104-7.

SIMON-CHAZOTTES, D., TUTOIS, S., KUEHN, M., EVANS, M., BOURGADE, F., COOK, S., DAVISSON, M.T. and GUENET, J.L. (2006). Mutations in the gene encoding the low-density lipoprotein receptor LRP4 cause abnormal limb development in the mouse. Genomics. 87, 673-677.

SMITH T.G. and TICKLE, C. (2006). The expression of Flrt3 during chick limb development. Int. J. Dev. Biol. 50: 701-704.

SOSHNIKOVA, N., ZECHNER, D., HUELSKEN, J., MISHINA, Y., BEHRINGER, R.R., TAKETO, M.M., CRENSHAW, E.B. and BIRCHMEIER, W. (2003). Genetic interaction between Wnt/beta-catenin and BMP receptor signaling during formation of the AER and the dorsal-ventral axis in the limb. Genes Dev. 17, 1963-1968.

SUMMERBELL, D., LEWIS, J.H. and WOLPERT, L. (1973). Positional information in chick limb morphogenesis. Nature. 244, 492-496.

SUMMERBELL, D. (1974). A quantitative analysis of the effect of excision of the AER from the chick limb-bud. J Embryol Exp Morphol. 32, 651-660.

SUN, X., LEWANDOSKI, M., MEYERS, E.N., LIU, Y.H., MAXSON, R.E. and MARTIN, G.R. (2000). Conditional inactivation of Fgf4 reveals complexity of signalling during limb bud development. Nat Genet. 25, 83-86.

SUN, X., MARIANI, F.V. and MARTIN, G.R. (2002). Functions of FGF signalling from the apical ectodermal ridge in limb development. Nature. 418, 501-508.

TABIN, C. and WOLPERT, L. (2007). Rethinking the proximodistal axis of the vertebrate limb in the molecular era. Genes Dev 21, 1433-1442.

TANAKA, M., TAMURA, K., NOJI, S., NOHNO, T. and IDE, H. (1997). Induction of additional limb at the dorsal-ventral boundary of a chick embryo. Dev Biol. 182, 191-203.

TANAKA, M., COHN, M.J., ASHBY, P., DAVEY, M., MARTIN, P. and TICKLE, C. (2000). Distribution of polarizing activity and potential for limb formation in mouse and chick embryos and possible relationships to polydactyly. Development, 127, 4011-4021.

TAVARES, A.T., TSUKUI, T. and IZPISÚA-BELMONTE, J.C. (2000). Evidence that members of the Cut/Cux/CDP family may be involved in AER positioning and polarizing activity during chick limb development. Development. 127, 51335144.

TICKLE, C. and MUNSTERBERG, A. (2001). Vertebrate limb development - the early stages in chick and mouse. Curr. Opin. Genet. Dev. 11: $476-481$.

TICKLE, C. (2003). Patterning systems-from one end of the limb to the other. Dev. Cell. 4, 449-458.

TODT, W.L. and FALLON, J.F. (1984). Development of the apical ectodermal ridge in the chick wing bud. J Embryol Exp Morphol. 80, 21-41.

TODT, W.L. and FALLON, J.F. (1986). Development of the apical ectodermal ridge in the chick leg bud and a comparison with the wing bud. Anat Rec. 215, 288304.

TOZER, S. and DUPREZ, D. (2005). Tendon and ligament: development, repair and disease. Birth Defects Res C Embryo Today. 75, 226-236.

TOZER, S., BONNIN, M.A., RELAIX, F., DI SAVINO, S., GARCÍA-VILLALBA, P., COUMAILLEAU, P., and DUPREZ, D. (2007). Involvement of vessels and PDGFB in muscle splitting during chik limb development. Development 134, 2579-2591.
TREICHEL, D., SCHOCK, F., JACKLE, H., GRUSS, P. and MANSOURI, A. (2003). $\mathrm{mBtd}$ is required to maintain signaling during murine limb development. Genes Dev. 17, 2630-2635.

VARGAS, A.O. and FALLON, J.F. (2005). The digits of the wing of birds are 1,2, and 3. A review. J. Exp. Zoolog. B Mol Dev Evol. 304, 206-219.

VOGEL, A., RODRÍGUEZ, C., WARNKEN, W. and IZPISÚA-BELMONTE, J.C. (1995). Dorsal cell fate specified by chick $L m \times 1$ during vertebrate limb development. Nature. 378, 716-720.

WANEK, N., MUNEOKA, K., HOLLER-DINSMORE, G., BURTON, R. and BRYANT, S.V. (1989). A staging system for mouse limb development. J. Exp. Zool. 249, 41-49.

WANG, C.K., OMI, M., FERRARI, D., CHENG, H.C., LIZARRAGA, G., CHIN, H.J., UPHOLT, W.B., DEALY, C.N. and KOSHER, R.A. (2004). Function of BMPs in the apical ectoderm of the developing mouse limb. Dev Biol. 269, 109-122.

WEATHERBEE, S.D., ANDERSON, K.V. and NISWANDER, L.A. (2006). LDLreceptor-related protein 4 is crucial for formation of the neuromuscular junction. Development. 133, 4993-5000.

WHEATLEY, S.C., ISACKE, C.M. and CROSSLEY, P.H. (1993). Restricted expression of the hyaluronan receptor, CD44, during postimplantation mouse embryogenesis suggests key roles in tissue formation and patterning. Development. 119, 295-306.

WOLPERT, L., TICKLE, C. and SAMPFORD, M. (1979). The effect of cell killing by $\mathrm{x}$-irradiation on pattern formation in the chick limb. J Embryol Exp Morphol. 50, 175-193.

XU, J., LIU, Z. and ORNITZ, D.M. (2000). Temporal and spatial gradients of Fgf8 and Fgf17 regulate proliferation and differentiation of midline cerebellar structures. Development. 127, 1833-1843.

YANG, Y. (2003). Wnts and wing: Wnt signaling in vertebrate limb development and musculoskeletal morphogenesis. In:" Birth Defects Research Part C: Embryo Today: Reviews".Wiley-Liss, Inc. Volume 69, Issue 4, Pages 305-317.

YANG, Y. and NISWANDER, L. (1995). Interaction between the signaling molecules Wnt7a and Shh during vertebrate limb development: dorsal signals regulate anteroposterior patterning. Cell 80, 939-947.

YANG, A., SCHWEITZER, R., SUN, D., KAGHAD, M., WALKER, N., BRONSON, R.T., TABIN, C., SHARPE, A., CAPUT, D., CRUM, C. and MCKEON, F. (1999). p63 is essential for regenerative proliferation in limb, craniofacial and epithelial development. Nature. 398, 714-718.

YOKOUCHI, Y., SASAKI, H. and KUROIWA, A. (1991). Homeobox gene expression correlated with the bifurcation process of limb cartilage development. Nature. 353,443-445.

YONEI-TAMURA, S., TAMURA, K., TSUKUI, T. and IZPISÚA-BELMONTE, J.C. (1999). Spatially and temporally-restricted expression of two T-box genes during zebrafish embryogenesis. Mech Dev. 80, 219-221.

ZAKANY, J., ZACCHETTI, G. and DUBOULE, D. (2007). Interactions between HoxD and Gli3 genes control the limb apical ectodermal ridge via Fgf10. Dev Biol. 306, 883-893.

ZUÑIGA, A., HARAMIS, A.P., MCMAHON, A.P. and ZELLER, R. (1999). Signal relay by BMP antagonism controls the SHH/FGF4 feedback loop in vertebrate limb buds. Nature. 401, 598-602.

ZUÑIGA, A., MICHOS, O., SPITZ, F., HARAMIS, A.P., PANMAN, L., GALLI, A., VINTERSTEN, K., KLASEN, C., MANSFIELD, W., KUC. S., DUBOULE, D., DONO, R. and ZELLER, R. (2004). Mouse limb deformity mutations disrupt a global control region within the large regulatory landscape required for Gremlin expression. Genes Dev. 18, 1553-1564.

ZUZARTE-LUIS V, and HURLE JM. (2005) Programmed cell death in the embryonic vertebrate limb. Semin Cell Dev Biol. 2005 16:261-269.

ZWILLING, E. (1956). Genetic mechanism in limb development. Cold Spring Harb Symp Quant Biol. 21, 349-354. 


\section{Further Related Reading, published previously in the Int. J. Dev. Biol.}

See our Special Issue Fertilization in honor of David Garbers and edited by P.M. Wassarman and V.D. Vacquier at: http://www.ijdb.ehu.es/web/contents.php?vol=52\&issue=5/6

See our Special Issue Limb Development edited by Juan Carlos Izpisua Belmonte and Juan Hurlé at: http://www.ijdb.ehu.es/web/contents.php?vol=46\&issue=7

Expression of Shisa2, a modulator of both Wnt and Fgf signaling, in the chick embryo Thomas A. Hedge and Ivor Mason Int. J. Dev. Biol. (2008) 52: 81-85

Expression and functions of FGF ligands during early otic development Thomas Schimmang Int. J. Dev. Biol. (2007) 51: 473-481

Isolation, genomic structure and developmental expression of Fgf8 in the short-tailed fruit bat, Carollia perspicillata

Chris J. Cretekos, Jian-Min Deng, Eric D. Green, NISC Comparative Sequencing Program, John J. Rasweiler and Richard R. Behringer Int. J. Dev. Biol. (2007) 51: 333-338

Isolation, genomic structure and developmental expression of Fgf8 in the short-tailed fruit bat, Carollia perspicillata

Chris J. Cretekos, Jian-Min Deng, Eric D. Green, NISC Comparative Sequencing Program, John J. Rasweiler and Richard R. Behringer Int. J. Dev. Biol. (2007) 51: 333-338

A comparative analysis of Meox1 and Meox2 in the developing somites and limbs of the chick embryo

Susan Reijntjes, Sigmar Stricker and Baljinder S. Mankoo

Int. J. Dev. Biol. (2007) 51: 753-759

Analysis of a new allele of limb deformity (Id) reveals tissue- and age-specific transcriptional effects of the Ld Global Control Region

Emilia Pavel, Wenning Zhao, Kimerly A. Powell, Michael Weinstein and Lawrence S. Kirschner

Int. J. Dev. Biol. (2007) 51: 273-281

The expression of Fat-1 cadherin during chick limb development Terence G. Smith, Nick Van Hateren, Cheryll Tickle and Stuart A. Wilson Int. J. Dev. Biol. (2007) 51: 173-176

The expression of FIrt3 during chick limb development Terence G. Smith and Cheryll Tickle Int. J. Dev. Biol. (2006) 50: 701-704

Nvbeta-actin and NvGAPDH as normalization factors for gene expression analysis in limb regenerates and cultured blastema cells of the adult newt, Notophthalmus viridescens

Sandy G. Vascotto, Shawn Beug, Richard A. Liversage and Catherine Tsilfidis Int. J. Dev. Biol. (2005) 49: 833-842

Genetic interaction of Gli3 and Alx4 during limb development Lia Panman, Thijs Drenth, Pascal teWelscher, Aimée Zuniga and Rolf Zeller Int. J. Dev. Biol. (2005) 49: 443-448

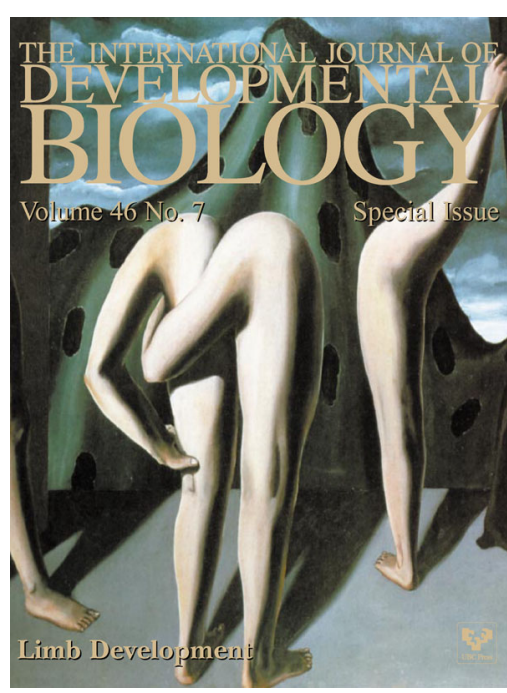

2006 ISI **Impact Factor $=3.577^{* *}$

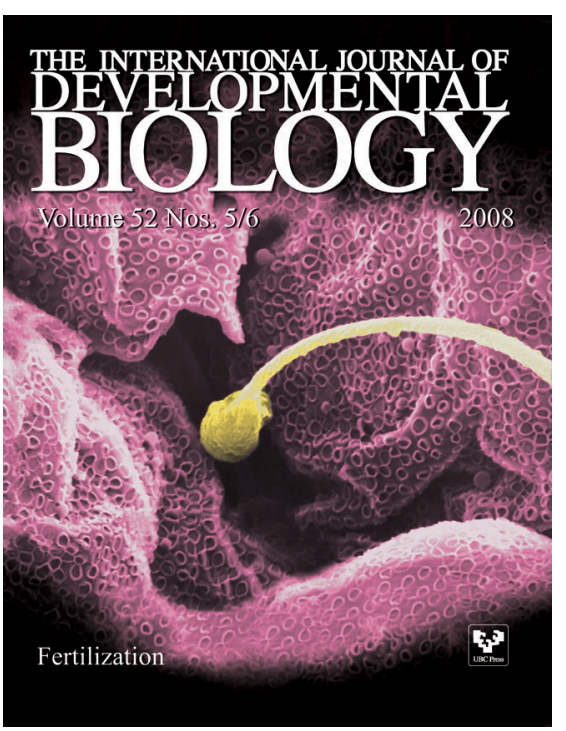

